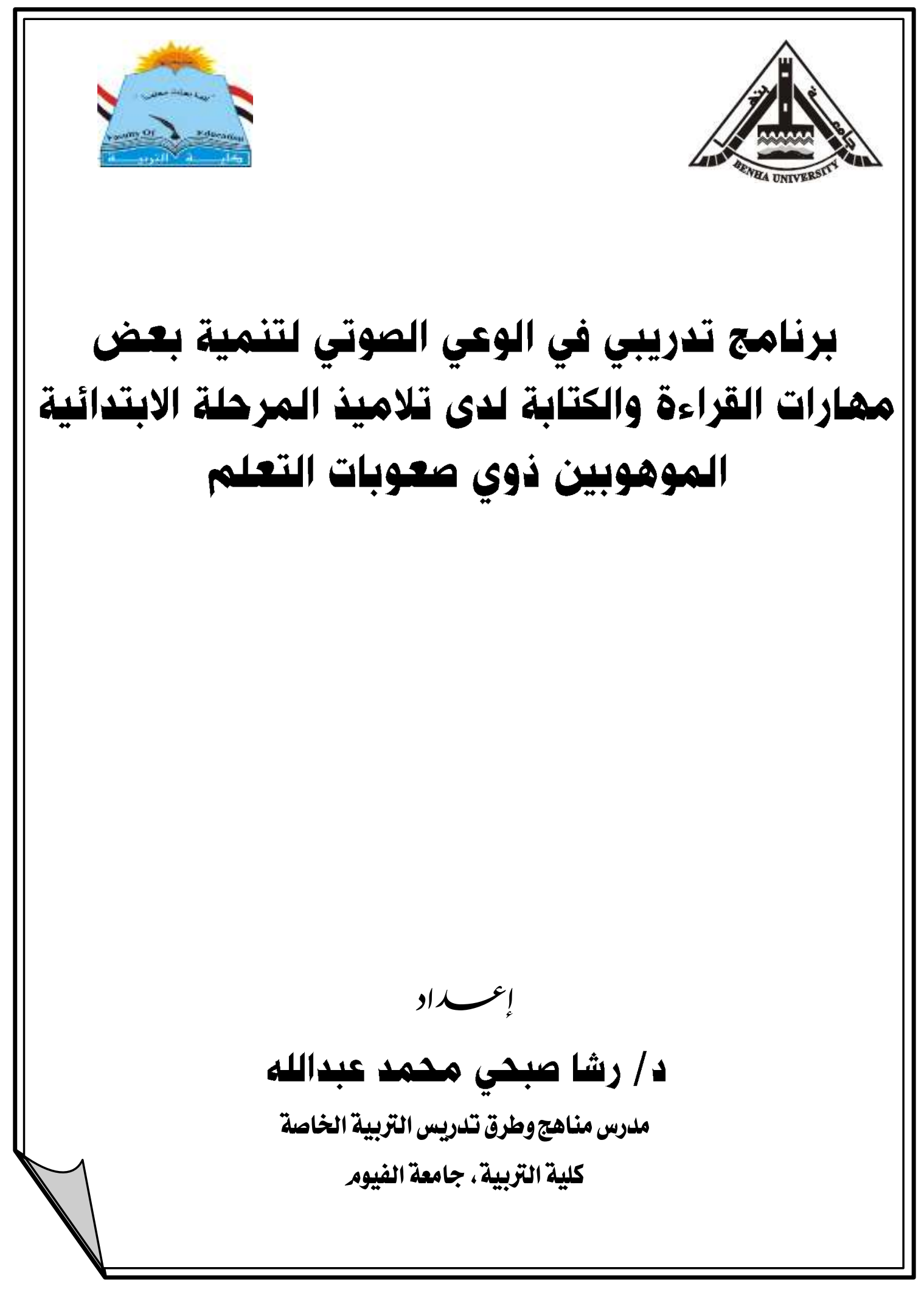




\title{
برنامج تدريبي في الوكي الصوتي لتنمية بعض مهارات القراءة والكتابة لدى تلاميذ المرحلة الابتائية الموهوبين ذوي صعوبات التعلم
}

\author{
!人年
}

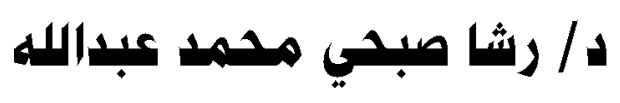

ملدرس مناهج وطرق تدريس التربية الخاصة

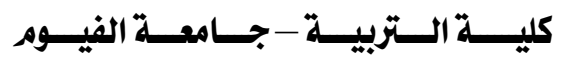

\section{ملث ص البدـــــ}

هدفت الدراسة إلى : تعرف أثر استخدام البرنامج القائم على الوعي الصوتي في تتمية بعض مهارات القراءة والكتابة لدى الموهوبين ذوي صعوبات التعلم. حيث تكونت عينة الدراسـة من (• () تلاميذ من تلاميذ الصف الثالث الابتدائي الموهوبين ذوي صعوبات التعلم في العام

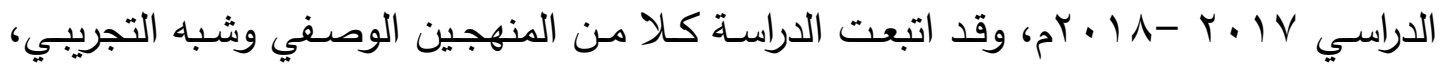
واستخدمت الدراسـة الأدوات الآتية : اختبار مهارات القراءة، واختبار مهارات الكتابـة، وكذلك

دليل المعلم، والبرنامج القائم على الوعي الصوتي، وقد توصلت الدراسة إلى النتائج الآتية: ا-توجد فروق ذات دلالة إحصائية بين متوسطى درجات تلاميذ المجموعة التجربيية فى التطبيقين القبلي والبعدي لاختبار مهارات القراءة و لاختبار مهارات الكتابـة لصسالح

$$
\text { التطبيق البعدي. }
$$

ץ- توجد فروق ذات دلالة إحصـائية بين متوسطى درجات تلاميذ المجموعة التجربيية في التطبيقين القبلي والبعدي في اختبار مهارات القراءة لصالح التطبيق البعدي. ץ-توجد فروق ذات دلالة إحصائية بين متوسطى درجات تلاميذ المجموعة التجربيية فى التطبيقين القبلي والبعدي فى اختبار مهارات الكتابة لصالح التطبيق البعدي. وفي ضوء النتائج التالية قدمت الدراسة مجموعة من التوصيات، والبحوث المقترحة.

الكلمات المفتاحية: مهارات القراءة والكتابة - الوعي الصوتي - الموهوبون ذوو صعوبات التعلم. 


\section{Abstract}

The study aimed to: Know the effect of using the program based on phonemic awareness in developing some reading and writing skills for gifted people with learning disabilities. Where the study sample consisted of (10) gifted third graders with learning disabilities.' in the 2017-2018 academic year, the study followed both descriptive and quasi-experimental approaches, and the study used the following tools: a test of reading skills, a writing skills test, as well as a guide The teacher and the program based on phonemic awareness. The study reached the following results:

1- There are statistically significant differences between the mean scores of students of the experimental group in the pre and post applications to test reading skills and to test writing skills in favor of post-application.

2- There are significant differences Of statistical differences between the mean scores of the experimental group students in the two applications pre and post test reading skills for post-application.

3- There are statistically significant differences between the mean scores of the experimental group students in the pre and post applications in the writing skills test in favor of post application. In light of the following results, the study presented a set of recommendations and proposed research.

Key words: Reading and Writing Skills - Voice Awareness -Gifted People with Learning Disabilities. 
تعتبر القراءة الوسيلة الأساسية لاكتساب المعلومات والخبرات، وأساس كل عملية تعليمية

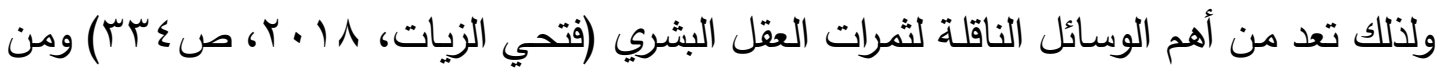
ثم فإن التعثر فيها قد ينشأ عنه تعثر في كافة ميادين التعلم الأخرى؛ وبالتالي فإن القراءة الجيدة

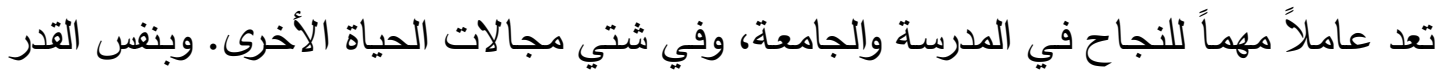
فإن الكتابة تلعب دوراً مهماً في كونها تمثل مهارة تعليمية ضرورية للنجاح الأكاديمي، وباعتبارها صيغة اتصالية علي درجة عالية من التعقيد. (عمر المغراوي، Y V V ص ص • Y). وتتجاوز كل من القراءة والكتابة حدود الإدراك البصري للرموز المكتوبة إلى حلها وفهم معانيها، والنطق بها، مع الفهم الدقيق لها ونقدها والربط بين حيثيات المادة المقروءة. (منصور

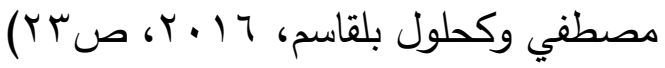
وتأتي أهمية القراءة والكتابة من أنها تحافظ علي الهوية ونقل التراث عبر الازمنة، لكن المتأمل لمعدلات انتثار صعوبة القراءة والكتابة يستثعر خطورتها، لأنها ليست قليلة، فهي حالة يكون فيها التلميذ مختلفاً عن الآخرين في عمليات التفكير، والتعلم، وتخزين المعلومات

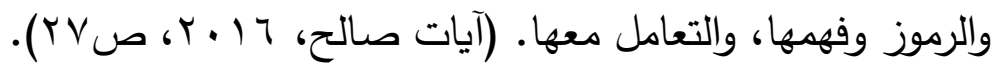
ونجد التلميذ لديـه اضطراب في استيعاب اللغـة مثل الحـروف والكلمـات، والتردد أو التوقف المتكرر عند بعض الكلمات خاصـة اذا كانت جديدة وإغفال بعضها، والتكرار الملحوظ لأخطاء التلميذ في التراءة، والخلط في ترتيب الحروف في الكلمة والصعوبة في التحليل الصوتي للكلمات؛ بينما تكون هذه الأخطاء قد انخفضت أو تلاشت للى التلاميذ المساوين له في العمر أو الذكاء، وبطبيعة الأمر فإن هذه الصعوبات قد تؤثر إلى حد كبير على مهارات الكتابة فيكون خط الطفل رديء مشوش يصعب قراءته، وقد يوجد تباين في أحجام الحروف والكلمات، وميل السطر

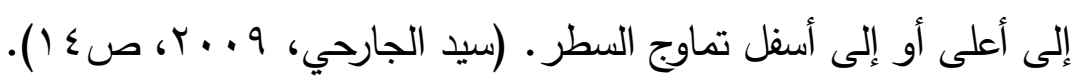
اهتمت الكثير من الدراسات الحديثة بالوعي الصوتي ودوره في تتمية مهارات اللغة؛ فهو يعد أحد مكونات عملية النظام الصوتي المستخدمة في اللغة المنطوقة والمكتوبـة. ويعد تتمية 
مهاراته وثيق الصلة بتنمية جميع المهارات اللغوية، الاستماع والتحدث والقراءة (أكرم إبراهيم،

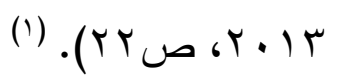

فالوعي الصوتي يعني امتلالك التلاميذ قدرات تتجاوز اللغة إلي ما وراء اللغة، ويقصد بذلك

قدرة التلاميذ علي التتغيه، وتقسيم الجملة الي كلمات والكلمات الي مقاطع، والمقاطع إلي أصوات.

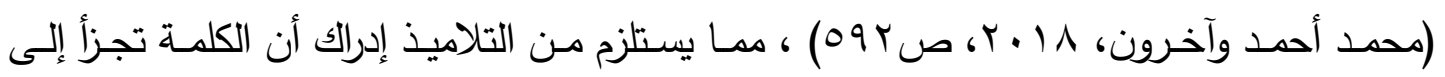

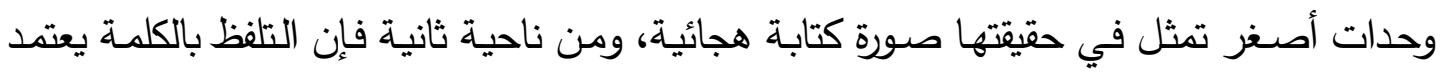
علي تجميع معلومات صوتية حول كل وحدة صوتية، ويساعد إدراك أصوات الوحدات التي تتثكل تئليهل

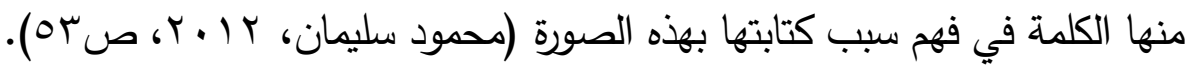
بـذلك يطـور الـوعي الصـوتي عند التلاميذ، الـوعي للقافيـة بشكل طبيعي وتلقـائي

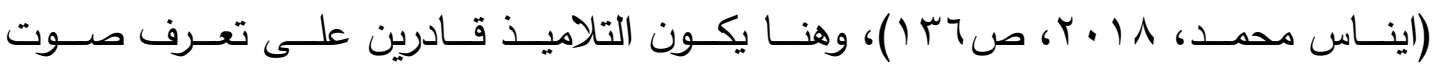
الحرف كي يقرأه، ويكون بـه كلمـات جديدة، ومـن هذا المنطلق تظهـر العلاقـة القويـة بين

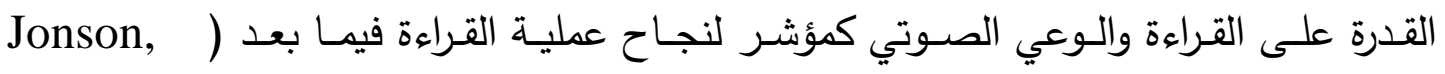

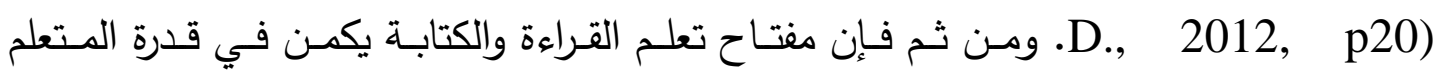

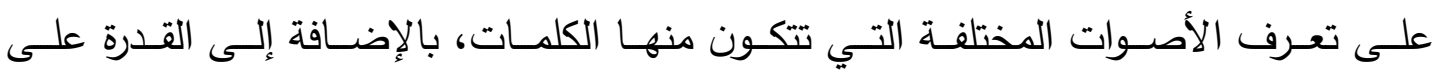
التفريق بين الأصوات في الكلمات المكتوبة (Zgonc, Y., 2010. p22).

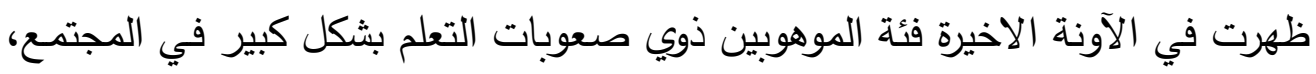

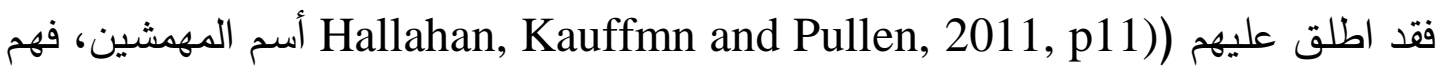
فئة غير قليلة في المجتمع، مما يشكل خطراً يفوق التوقعات، فالتلاميذ الموهوبين ذوي صعوبات التعلم قدراتهم العقلية فائقة التصور ، ولكن يظهر لديهم انخفاض مستوي أدائهم في اي مجال

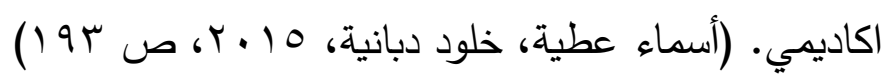
وبالرغم مما يتميز به الموهوبين ذوي صعوبات التعلم من قدرة عقلية عالية إلا أن لديهر الهر

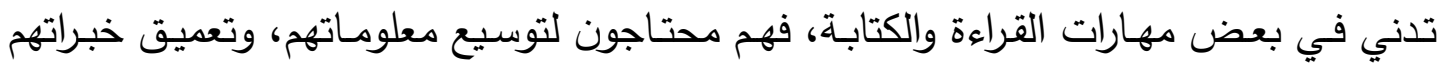

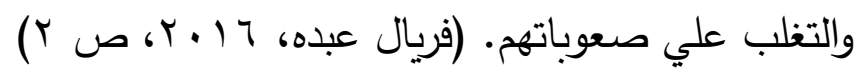

( () سار التوثيق في متن الدراسة على النحو الآتي: (اسم الباحث أو المؤلف: سنة النشر، رقم الصفحة أو الصفحات في المرجح. 


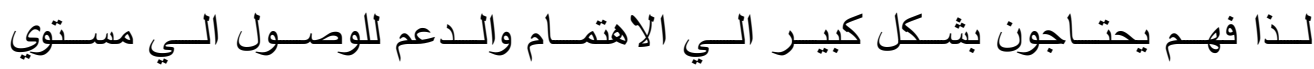

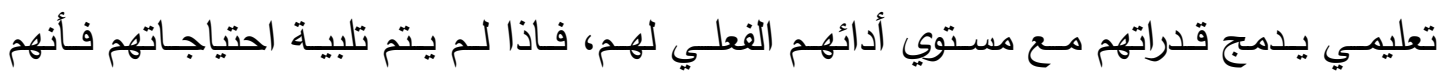

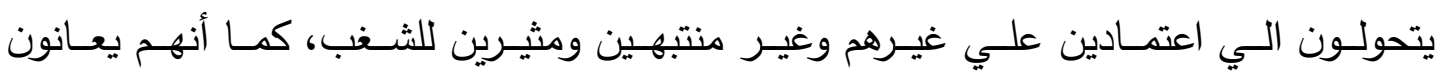
من الإحباط والفثل (Lerner, J. \& Kine, 2016, p15)

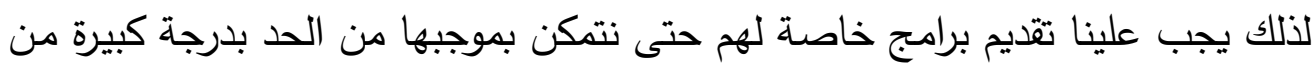
تلك الآثار السلبية لمثل هذه الصعوبات.

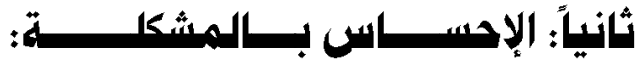
ينبع الإحساس بمثكلة الدراسة من خلال ما يلي:

\section{أولاً : الاطلاع على نتائج البحوث والدراسات السابقة:}

بالرغم من أهمية القراءة والكتابة إلا أن الواقع يثير إلي تدني مهارات القراءة والكتابة الكتابة

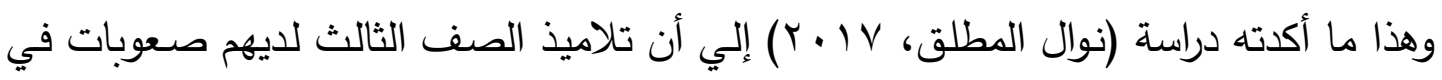

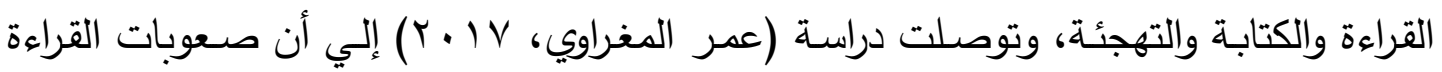

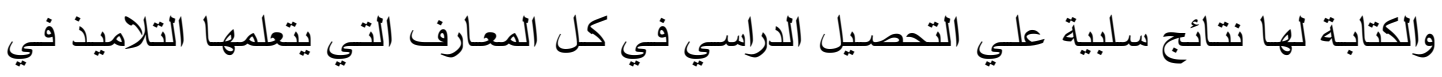

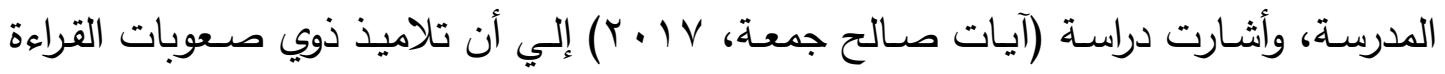

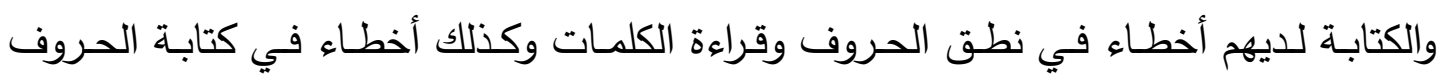

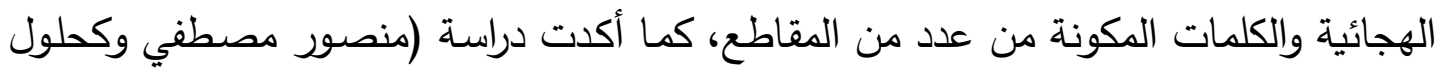

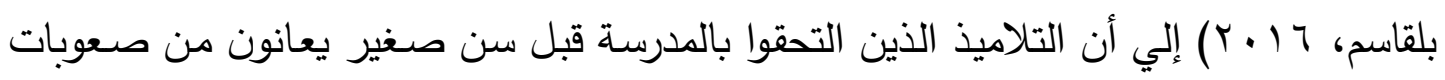
التعلم الأكاديمية مثل (القراءة والكتابة والحساب). كما أشارت دراسة (Schramm,2016) إلي وجود انخفاض في مستويات التلاميذ في والئي

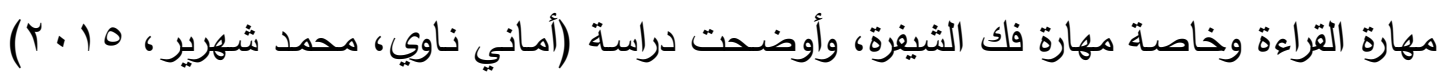

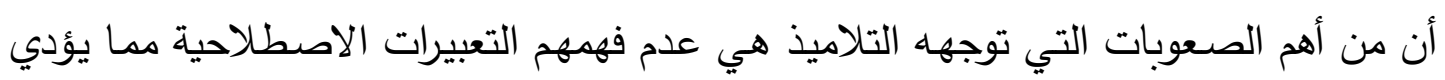
إلي سوء الفهم عند التعامل مـع النصوص العربية التي تحتوي علي تلك التعبيرات، وأظهرت

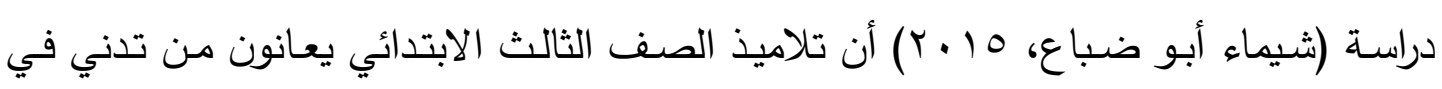
مهارات التعبير الكتابي.

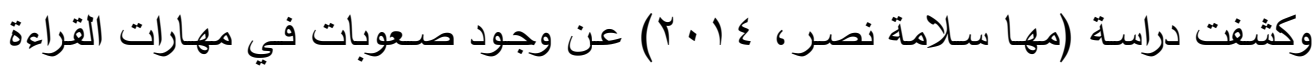

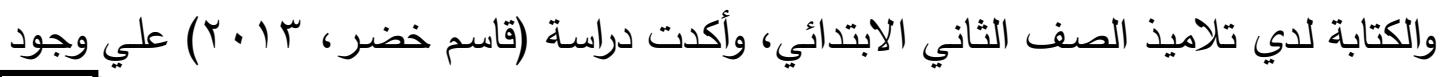


صعوبات في مهارات في القراءة والكتابة لاي تلاميذ الصف الرابع الابتدائي، وأظهرت دراسة

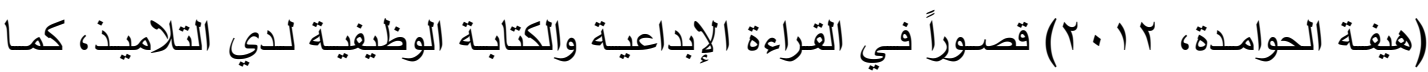

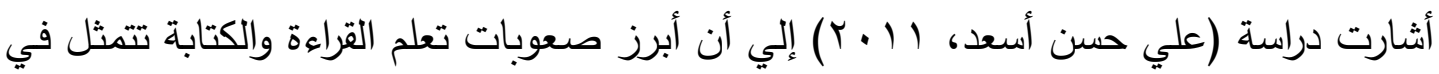
تعثر الطفل في القراءة والكتابة وكثرة المحو والضغط علي التعل القلم.

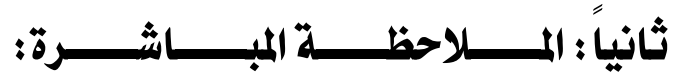

حضرت الباحثة مجموعة من الحصص الدراسية ببعض فصول تلاميذ الصف الثالث

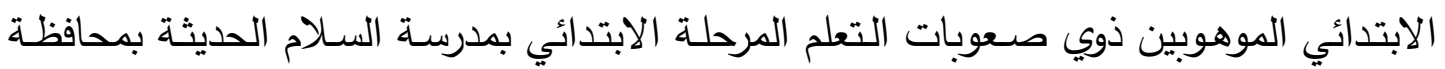

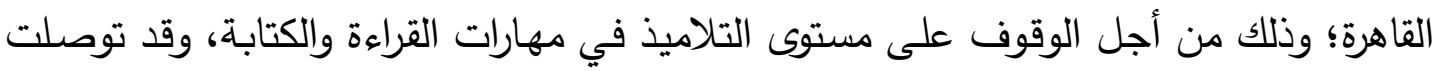
الباحثة إلى مجموعة من الملاحظات:

يوجد ضـف في مهارات القراءة للى تلاميذ الصف الثالث الابتدائي الموهوبين ذوي صـوبات التعلم، مثل: تعرف رسم الحروف مـع الحركـات الثثلاث (الفتحـة والكسرة

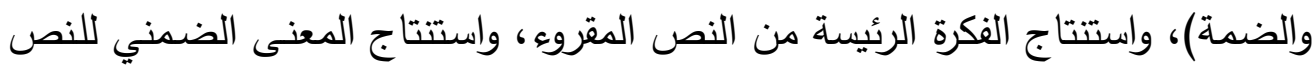

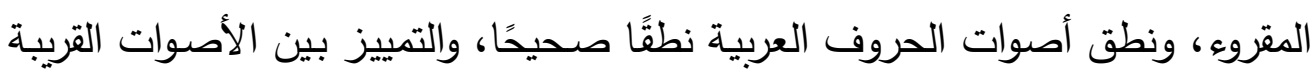
في المخرج، ونطق الكلمات دون حذف أو إضافة أو إبدال.

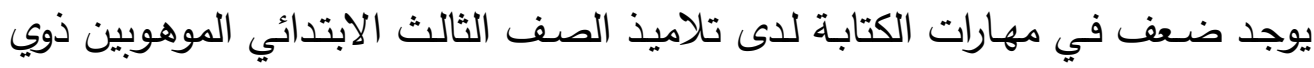
صعوبات التعلم، مثل: كتابة الحروف بخط واضحَ، وكتابة كلمات من حروف معطاة،

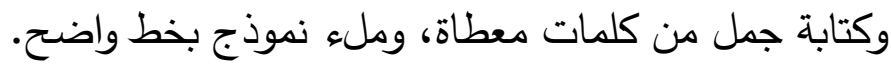

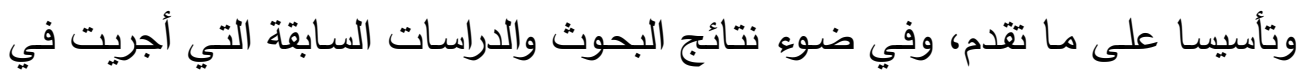

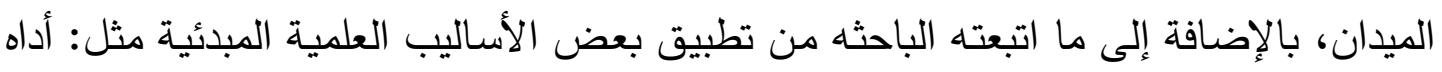

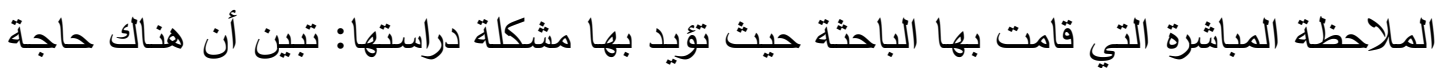

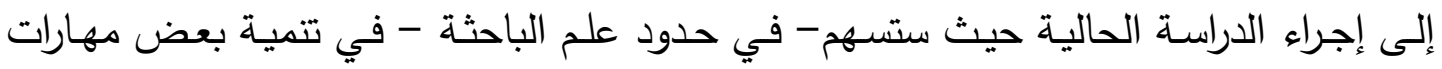

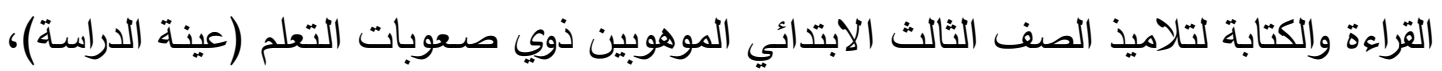
وخاصة أن الباحثة لم تتعرض لأية دراسة تتاولت متغيرات الدراسة الحالية.

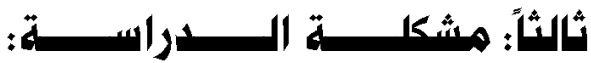

تتحدد مشكلة الدراسـة في تدني مستوى تلاميذ الصف الثالث الابتدائي في مهارات

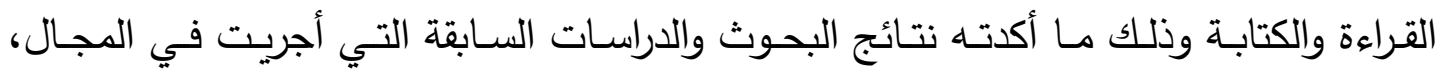


بالإضـافة إلى مـا قامت به الباحثة من ملاحظة مباشرة للتلاميذ ؛ لذا يمكن صياغة مشكلة

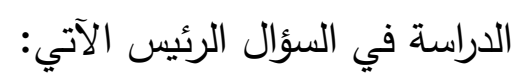

× ما أثر برنامج تدريبي في الوعي الصوتي لتنمية بعضمهارات القراءة والكتابة لاى تلاميذ المرحلة الابتدائية الموهوبين ذوي صعوبات التعلم؟ بريج وقد تفرع من هذا السؤال الرئيس الأسئلة الفرعية الآتية: 1- مــــــــارات القـراءة اللازمــة لتلاميــذ الصــف الثالــث الابتــائي الموهـوبين ذوي

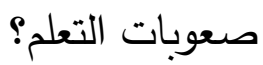
ץ- مــــــــارات الكتابـة المناسـبة لتلاميـذ الصـف الثالــث الابتــائي الموهـوبين ذوي صعوبات التعلم؟ r- ما البرنامج التدريبي المقترح لتتمية بعض مهارات القراءة والكتابة لدى تلاميذ الصف الثالث الابتدائي الموهوبين ذوي صعوبات التعلم؟ ع - ما فاعلية البرنامج التدريبي المقترح لتتمية بعض مهارات القراءة والكتابة لدى تلاميذ الصف الثالث الابتدائي الموهوبين ذوي صعوبات التعلم؟

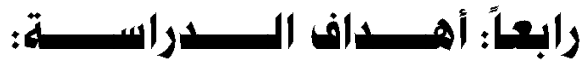

$$
\text { استهدفت الدراسة الحالية تحقيق ما يلي: }
$$

1- تحديـــــــارات القـراءة اللازمــة لتلاميـذ الصـف الثالـث الابتــائي الموهـوبين ذوي

$$
\text { صعوبات التعلم. }
$$

ץ- تحديـــــــارات الكتابـة المناسـبة لتلاميـذ الصـف الثالـث الابتـدائي الموهـوبين ذوي

$$
\text { صعوبات التعلم. }
$$

r- بناء برنامج قائم علي الوعي الصوتي لتتمية بعض مهارات القراءة والكتابة لدى تلاميذ الصف الثالث الابتدائي الموهوبين ذوي صعوبات التوعل التعلم. ع - تعرف فاعلية البرنـامج القائم على الوعي الصـوتي في تتميـة بعض مهارات القراءة والكتابة لاى تلاميذ الصف الثالث الابتدائي الموهوبين ذوي صعوبات التعلم. 


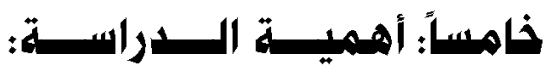

استمدت هذه الدراسة أهميتها فيما يمكن أن تفد به في:

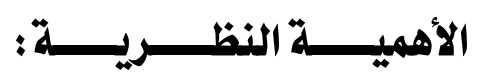

ترجع أهمية الدراسة الحالية إلي ندرة البحوث والدراسات التي تتاولت مهارات القراءة

والكتابة للموهوبين ذوي صعوبات التعلم •

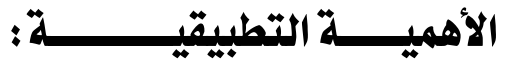

يرجى أن يستفيد من الدراسة الحالية:

ا - تلاميذ الصف الثالث الابتدائي الموهوبين ذوي صعوبات التعلم:

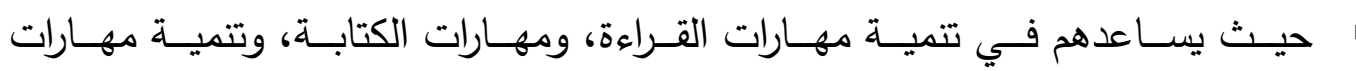

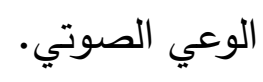

يساعد التلاميذ في الوقوف على مهارات القراءة ومهارات الكتابة، وتحديد المهارات التي

$$
\text { تحتاج إلى تتمية. }
$$

\section{ب- معلمو المرملة الابتدائية:}

$$
\text { حيث يساعدهم في: تصني }
$$

هوير تدريس مهارات القراءة ومهارات الكتابة لدى التلاميذ.

$$
\text { تحديد مستوى أداء التلاميذ في القراءة والكتابة. }
$$

هاستخدام الوعي الصوتي ومهاراته، في تحسين أداء التلاميذ في القراءة والكتابة.

"l - مخططو وواضعو مناهيج ذوي صعوبات التعلم:

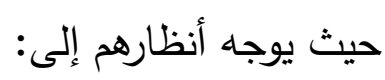

" تضمين أنشطة الوعي الصوتي في مناهج ذوي صعوبات التعلم.

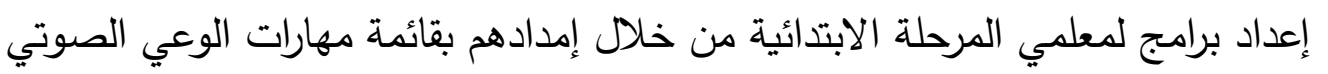

اللازمة للتلاميذ.

إعداد دليل لمعلمي المرحلة الابتدائية في مهارات القراءة والكتابة قائم على استخدام

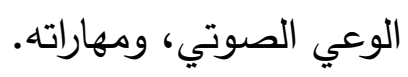


يفتح هذا البحث مجالًا للدراسات والبحوث في الوعي الصوتي ومهاراته، واستخدامه في تتمية بعض مهارات القراءة والكتابة.

\section{سادساً: فــروض الســراسيسة:}

اختبرت الدراسة صحة الفروض الآتية:

1-توجد فروق ذات دلالة إحصائية بين متوسطى درجات تلاميذ المجموعة التجرببية فى

التطبيقين القبلي والبعدي لاختبـار مهارات القـراءة ولاختبـار مهـارات الكتابـة لصـالح

التطبيق البعدي.

ץ- توجد فروق ذات دلالة إحصائية بين متوسطى درجات تلاميذ المجموعة التجربيية في

التطبيقين القبلي والبعدي في اختبار مهارات القراءة لصالح التطبيق البعدي.

ץ- توجد فروق ذات دلالة إحصائية بين متوسطى درجات تلاميذ المجموعة التجرببية فى

التطبيقين القبلي والبعدي فى اختبار مهارات الكتابة لصالح التطبيق البعدي.

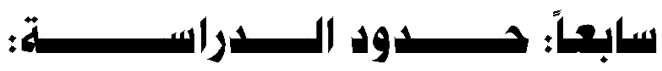

اقتصرت الدراسة على الحدود الآتية:

ا- الحدود المكانيـة: تلاميذ الصف الثالث الابتدائي الموهوبين ذوي صسوبات التعلم -

مدرسة (السلام الحديثة) - محافظة القاهرة.

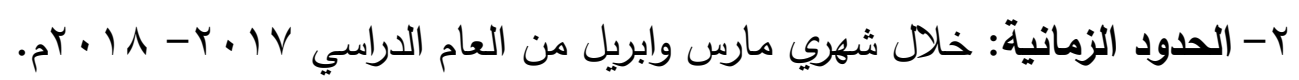

ب- الحدود الموضـوعية: تطبيق برنـامج قائم علي الوعي الصـوتي (مـن إعداد الباحثة)

لتنميـة بعض مهارات القراءة والكتابـة لتلاميذ الصف الثالث الابتدائي الموهوبين ذوي

صعوبات التعلم.

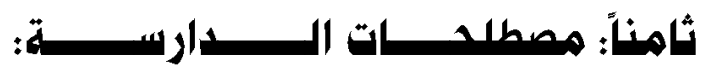

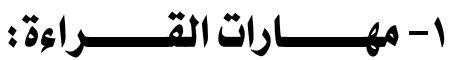

هي تلك المهارات التي أجمع الخبراء والمتخصصون علي أهميتها، لكي يجيد التلميذ

القراءة بطريقة صحيحة، فمهارة القراءة تثمل على إكمال الكلمة بالحرف الناقص، واختيار شكل

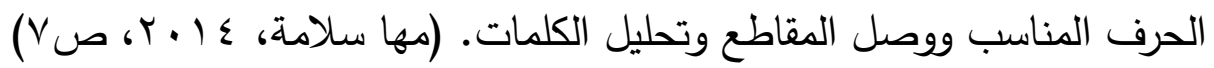




\section{ويقصد بمهارات القراءة في الدراسة الحالية:}

هي تلك المهارات التي توصلت إليها الباحثة من خلال قائمة مهارات القراءة التي قامت

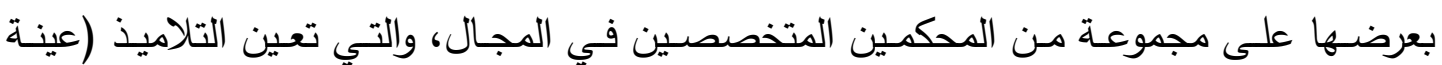

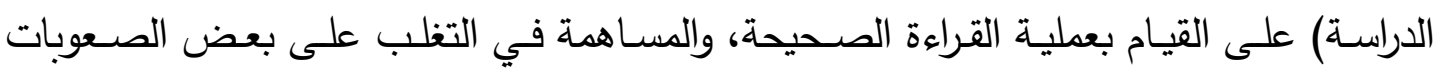
القرائية لديهم، وقد اعتمدت الباحثة على تلك المهارات التي حظيت بنسبة تكرار ، ^ \% فأكثر من إجمالي تكرارات آراء المحكمين على القائمة المعدة لذلك، وهذه المهارات هي: مهارة (التعرف، والنطق، والفهم) وقد تم قياسها بالاختبار وبطاقة الملاحظة الذين أعدتها الباحثة لهذا الغرض.

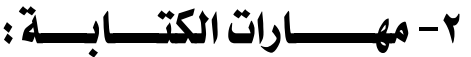

هي مجموعة من الأداءات التي يقوم بها التلميذ في أثناء الكتابة، لتكون كتابتهم دقيقة وصحيحة، وتثمل تكوين كلمات من حروف وإكمال العبارات وترتيب الكلمات والجمل وكتابة ما

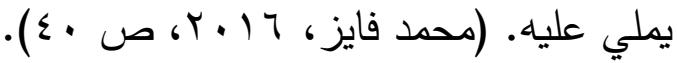

$$
\begin{aligned}
& \text { ويقصد بمهارات الكتابة في الدراسة الحالية: }
\end{aligned}
$$

هي تلك المهارات التي توصلت إليها الباحثة من خلال قائمة مهارات الكتابة التي قامت بعرضها على مجموعة من المحكمين المتخصصين في المجال، والتي تعين التلاميذ (عينـة

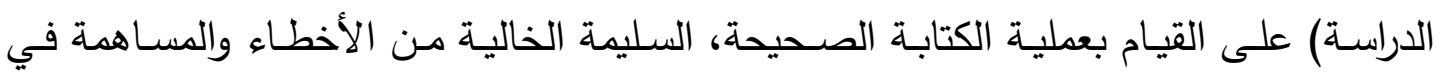
التغلب على بعض الصعوبات الكتابية لديهم، وقد اعتمدت الباحثة على تلك المهارات التي حظيت بنسبة تكرار ، ^ \% فأكثر من إجمالي تكرارات آراء المحكمين على القائمة المعدة لذلك، وهذه المهارات هي: مهارة (الرسم الكتابي، والتعبير الكتابي، وجودة الكتابة) وقد تم قياسها بالاختبار الذي أعدته الباحثة لهذا الغرض.

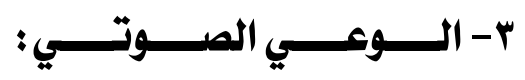
يعرف الوعي الصـوتي علي أنـه القدرة علي معرفـة أمـاكن إنتاج الأصسوات اللغويـة، وكيفيـة إخراج هذه الأصـوات، والكيفيـة التي تشكل فيهـا هذه الأصـوات مـع بعضـها لتكوين الكلمات والجمل والألفاظ، مع القدرة علي إدراك التثابه والاختلاف بين الأصوات سواء جاءت

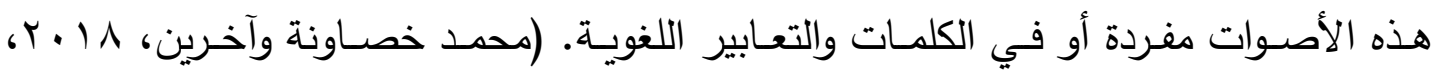


صوه)، كمـا يعرف علي أنـه القدرة علي المعالجـة الصـوتية ذات الصـلة القويـة لتعلم القراءة

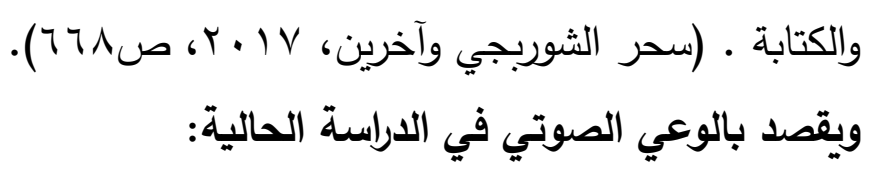

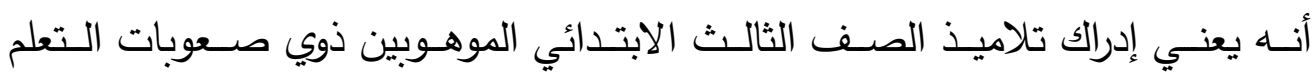
لأصوات الحروف الهجائية المنطوقة, والكيفية التي تتشكل بها لتكون مقاطع صوتية وكلمات, وإدراك التشابه والاختلاف بينهما.

\section{ك- الموهوبين ذوي صعوبات التعلم:}

هم من لديهم موهبة ظاهرة وقدرات عالية فائقة في مجال أو أكثر، ومع ذلك يظهرون تفاوتاً كبيراً في مجال أكاديمي محدد وبين مستوي إنجازهم المتوقع المعتمد علي قدراتهم العقلية.

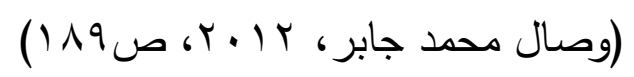

ويقصد بالموهوبين ذوي صعوبات التعلم في الدراسة الحالية: أنهح هم أولئك التلاميذ الذين يملكون مواهب أو إمكانات عقلية فائقة غير عادية ظاهرة تمكنهم من تحقيق مستويات أداء اكاديمية عالية ولكنهم يعانون من صعوبات تعلم في مهارات القراءة والكتابة.

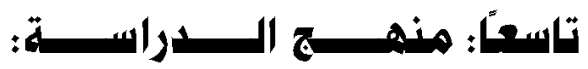

اعتمدت الدراسة على كل من المنهجين الآتيين:

• المنهج الوصفي: في إعداد الإطار النظري للدراسة، والإفادة من الدراسات السابقة.

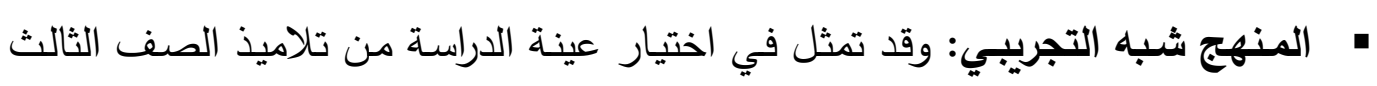

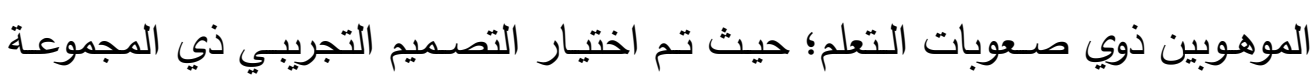

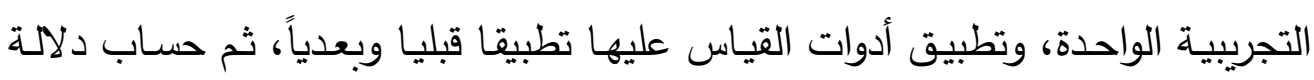
الفروق بين التطبيقين.

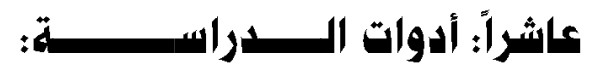

$$
\text { تمثلت أدوات الدراسة فى: }
$$

• أدوات جمـع البيانـات: قائمـة مهارات القراءة وقائمـة مهارات الكتابـة للتلاميذ الصـف تصف الثالث الابتدائي الموهوبين ذوي صعوبات التعلم. 
• الأدوات الإحصـائية: اختبار مهارات القراءة واختبار مهارات الكتابة و بطاقة تقدير الأداء في مهارات النطق للتلاميذ الصف الثالث الابتائي الموهوبين ذوي صعوبات التعلم.

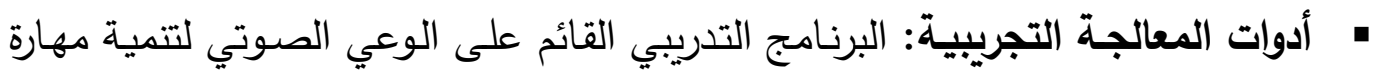
والكتابة للتلاميذ الصف الثالث الابتدائي الموهوبين ذوي صعوبات التعلم ودليل المعلم.

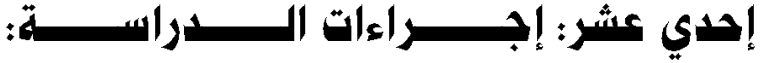

سارت إجراءات الدراسة وفق الخطوات التالية:

هالاطـلاع على الأدبيات والدراسـات السابقة المتصلة بالدراسـة، والخاصـة ب (مهارات

$$
\text { القراءة والكتابة- الوعي الصوتي - الموهوبين ذوي صعوبات التعلم). }
$$

إعداد أدوات الدراسـة: قائمـة مهارات القراءة وقائمسة مهارات الكتابة - اختبار مهارات القراءة واختبار مهارات الكتابة - بطاقة تقدير الأداء في مهارات النطق - البرنـامج

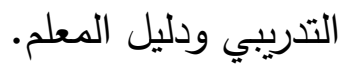

$$
\begin{aligned}
& \text { التحكيم على أدوات الدراسة. } \\
& \text { التطبيق الميدانى للأدوات. } \\
& \text { - إجراء العمليات الإحصائية، ورصد النتائج. } \\
& \text { " تقديم التوصيات والمقترحات. }
\end{aligned}
$$

\section{الإطار النظري والدراسات ذات الصلة}

تعرض الدراسة في هذا الجزء الإطار النظري، والدراسات والبحوث المرتبطة وفق ثلاث

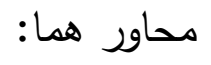

المحور الأول: مفهوم القراءة وأهميتها ومهاراتها وأهدافها، ومفهوم الكتابة وأهميتها ومهاراتها

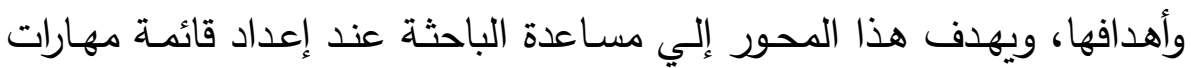

$$
\text { القراءة وقائمة مهارات الكتابة. }
$$

المحور الثاني: مفهوم الوعي الصوتي وأهميته ومهاراته ومستوياته، ويهدف هذا الدحور إلى وهى

مساعدة الباحثة عند إعداد البرنامج الذي يمكن من خلالها تتمية بعض مهارات القراءة والكتابة للتلاميذ الصف الثالث الابتدائي الموهوبين ذوي صعوبات التعلم. 
المحسر الثالثث: مفهوم الموهوبين ذوي صـوبات التعلم وتصنيفهر وخصائصـه، الإفادة من نتائج البحوث والدراسـات في هذا المجال، وفيمـا يلي تفصيل للمحاور على النحو التالي: - n

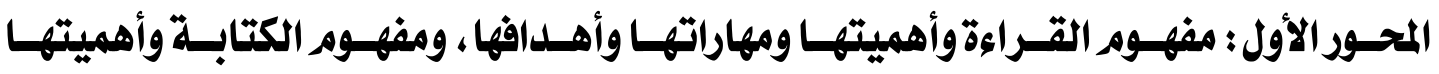

\section{ومهاراتها وأهدافها:}

\section{أ) مفهــــــم مهــــارات القــــــاءة :}

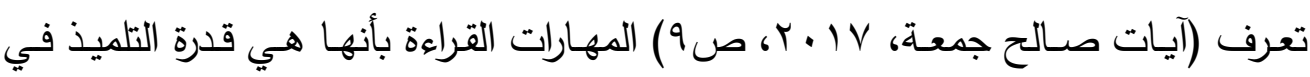
المرحلة الأساسية علي نطق الحروف نطقاً سليماً وقراءة الكلمات المكونة من هذه الحروف بأقل قدر

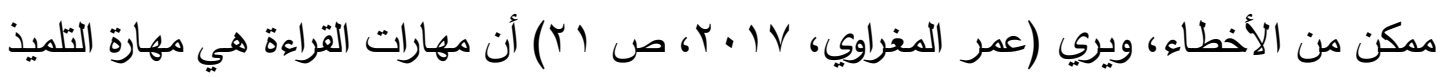
علي استخراج استتتاجات من النص المدروس واستخلاص الفكرة الرئيسية للنص وشرحها، تذكر

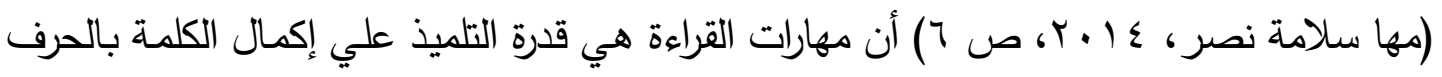
النـاقص واختيـار شكل الحـرف المناسـب ووصـل المقاطع وتوظيف الأسـماء والتميز بـين المفـرد والمثي والجمع واستخدام أدوات الاستفهام واستخراجها وحل الكلمات ثم يكون كلمة جديدة.

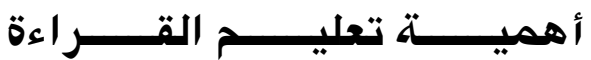

1- وسـيلة مـن وسـائل غـرس الأخـاق الحميـدة في نفـوس التلاميـذ. (فتحـي الزيـات،

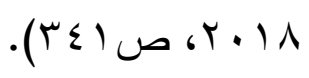

ץ- تمكن التلميذ من توليد المعاني وانتاج الأفكار وتتشيط الذهن.

ب- هــي المــدخل الحقيقـي لتتميـة التفكيـر فـي مسـتوياته. (بركــة محمـــ عـوض،

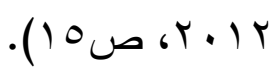

$$
\begin{aligned}
& \text { ع - تتمية الاتجاهات والقيم المرغوب بها. (مها سلامة، ع ( ـ ب، صس ()). }
\end{aligned}
$$

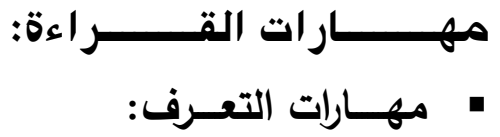

ويقصد بها التعرف علي الكلمة وعلي الجملة، والتمييز الصوتي بين نطق الحروف، وأيضـا التمييز البصري بين أشكال الحروف، وربط الرموز الصوتية بالرموز المكتوبة، وتعرف

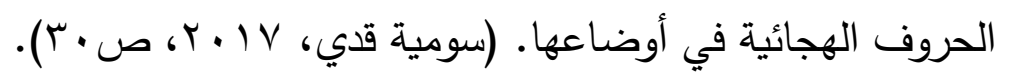


وتعني نطق وتمييز الأصـوات المفخمـة والأصـوات المرققة، والتمييز بين الأصـوات المهموسـة والأصــوات المهجـورة، وأيضـا التمييز بـين الأصـوات الثـديدة والرخـوة والمتوسـة.

$$
\begin{aligned}
& \text { (منصوري مصطفي، عروم وافية، } 10 \text { • ب، ص0 1) } \\
& \text { • مهـــارات الفهـــــ }
\end{aligned}
$$

وتتمثل في القدرة علي فهم الكلمات من السياق واختيار المعني، القدرة علي القراءة في وحدات فكريـة، والقدرة علي الأفكار الرئيسية وفهمها، والقدرة علي الاستنتاج. (آيات صـالح، $\cdot(r \cdot) \cdot r \cdot 17$

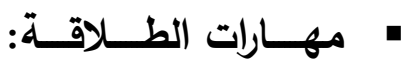
ويقصـد بها نطق الجمـل في صـورة تامـة، والأداء باستمرار دون تكرار، عدم إضـافة حرف أو أكثر إلي الكلمة، وأيضا عدم الإبدال والحذف، حسن الوقف عند إتمام المعني. (محي

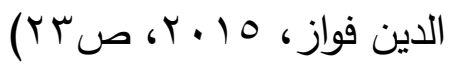

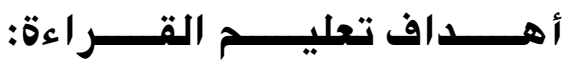

ا- تتمية قدرة التلميذ علي القراءة وتدريبه علي النطق الصحيح.

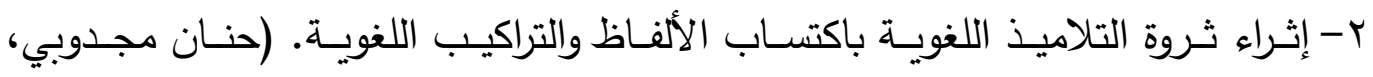

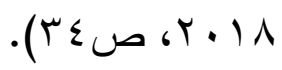

r- جعل القراءة نشاطا ممتعا عند التلميذ للاستمتاع بوقت فراغه . ع - تعليم التلاميذ كيفية فهم المقروء فهما صحيحا وتمييزه بين الأفكار الأساسية والجزئية. 0- الإقبـال علـي المشـاركة في الأنثـطة المنهجيـة وغيـر المنهجيـة. (مهــا سـلامة،

$$
\text { () } \leqslant \text { ص r. I I }
$$

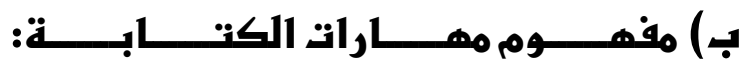

تعرف (آيات صالح جمعة، V V P r، ص 9) مهارات الكتابة بأنها هي قدرة التلميذ علي

كتابة الحروف الهجائية والكلمات المكونـة من مقاطع والحروف بخط واضـح وبأقل قدر ممكن من أخطاء الكتابة، وتذكر (مها سلامة نصر ، ع ( . ، ص V V) أن مهارات الكتابة هي تكوين كلمات لها معني بدلالة الصورة وتكوين كلمات من الحروف وإكمال العبارات وترتيب الكلمات وترتيب الجمل والتعبير عن الصورة بجمل مفيدة وكتابة ما يملي عليه غيبا، كما عرفها (زهير 


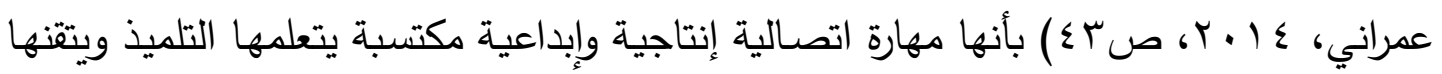
كنشاط ذهني يقوم علي التفكير ويحتاج إلي تناسق بصري سمعي حركي وانسياب الأفكار والطلاقة في استخدام اللغة وهي علي درجة عالية من التعقيد لأنها تتضمن التفاعل بين التعبير

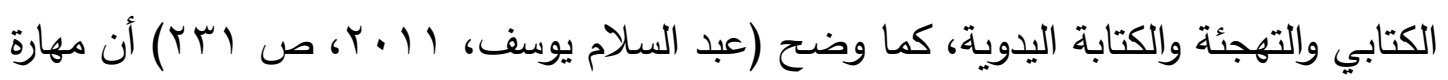

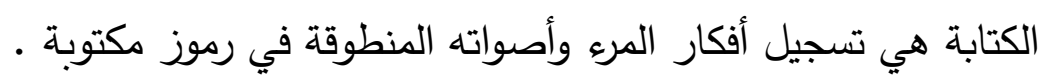

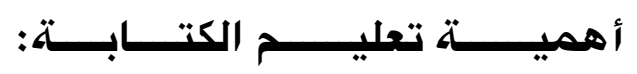

1- حافظة للتراث.

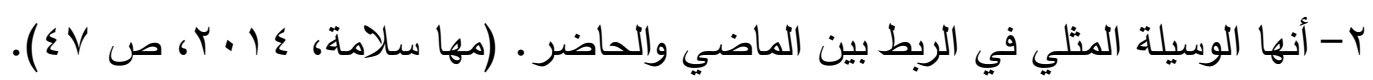
r- أنها واحدة من أهم الوسائل في الاتصال الفكري بين الجنس البشري علي مر العصور

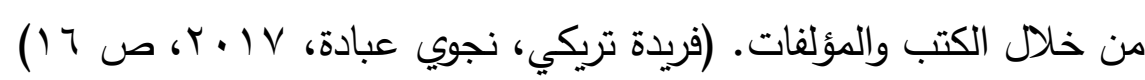
ع - هي من وسائل التنفيس عن النفس والتعبير عما يجيش بالخواطر والصدور .

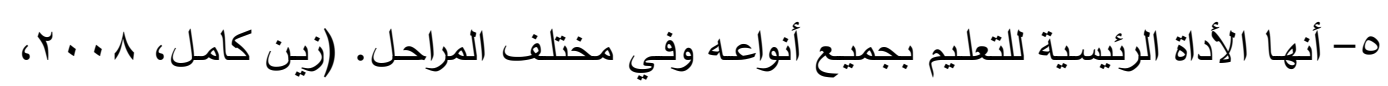

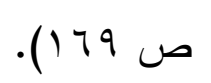
צ- للكتابة أثر اجتماعي، حيث أنها تسهم في تكوين الرأي العام وتقارب وجهات النظر والتفاهم بين الأفراد، وبالتالي تقوي الروابط بين أفراد المجتمع الواحد.

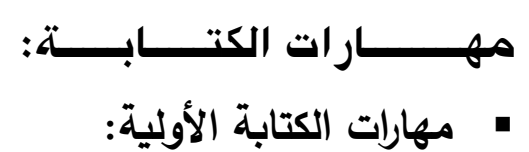

وتتمثل في القدرة علي اللمس ومد اليد ومسك الأشياء وإفلاتها، والقدرة علي تمييز التشابه والاختلاف بين الأشياء والقدرة علي استعمال اليدين بكفاءة. (فريدة تريكي، نجوي عبادة،

$$
\begin{aligned}
& \text { (ro } \\
& \text { • مهارات الرسم الكتابي: }
\end{aligned}
$$

ويقصد بها مراعاه قواعد الوقف والوصل والمد في الكلام، واتقان مواطن علامات الترقيم

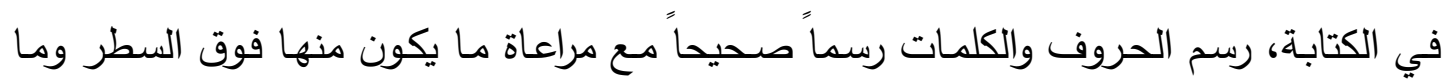
ينزل عنه ومراعاة المسافات اللازمة بين الكلمات والحروف. 


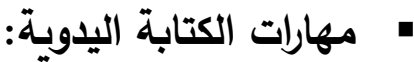

وتعني القدرة علي مسك القلم أداه الكتابة. وتحريكه إلي الأعلى وإلي الأسفل وبشكل

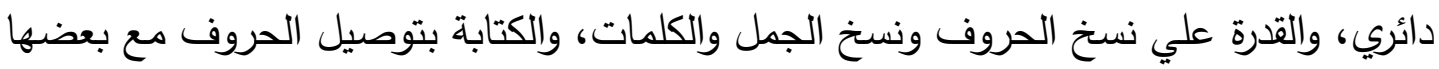

$$
\begin{aligned}
& \text { البعض. (آيات صالح، } 17 \text { • Y، ص r Tr). } \\
& \text { • مهـــارات التهجئُ الـــة: }
\end{aligned}
$$

وتتمثل في تمييز حروف التهجئة، وتمييز الكلمات، وتمييز التشابه والاختلاف بين

الكلمات، وأيضا تمييز الأصوات المختلفة في الكلمة، والربط بين الصوت واتئهن والحرف، واستعمال

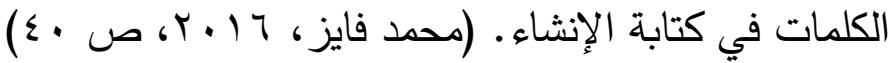

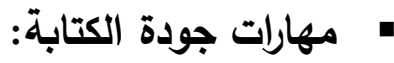

ويقصد بها مراعاه حسن الخط ووضوحه، تجنب الأخطاء الإملائية في الكتابة، مراعاه التنسيق والتوازن الصحيح في كتابة الأحرف.

$$
\text { • مهارات التعبير الكتابي: }
$$

وتتمثل في كتابة الجمل وأثشباه الجمل، واستعمال علامات الترقيم والقواعد البسيطة

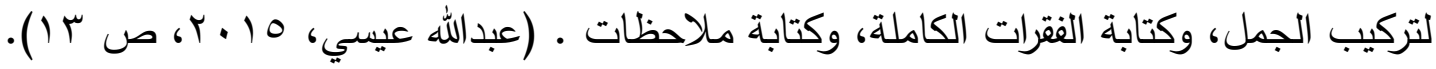
وترى الباحثة أن تعليم التلاميذ للمهارات الكتابة يرتكز علي إجراءات من من أهمها:

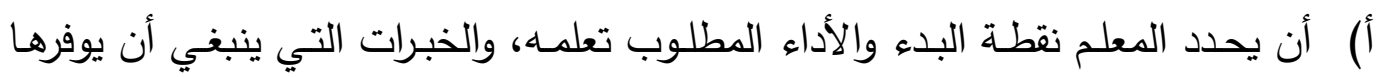
لتلاميذه، والمهارات التي يريد إكسابها لهم. لهم. ب) تحليل المهارة الكلية إلي مهارات جزئية. ج) تدريب التلميذ علي المهارة، وتوفير المواقف المناسبة للتدريب، وأيضا تعريفه بأخطائه. د) تصميم التدريبات بحيث تكفل مرونة في الأداء، مع مراعاه الفروق الفردية.

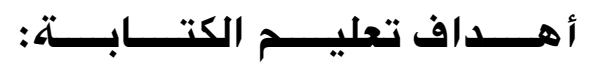

1- التدريب علي كتابة ما يسمع بصورة صحيحة. r- التدريب عل كتابة الكلمات بشكل صحيح وتثبيت صورتها في الذهن.

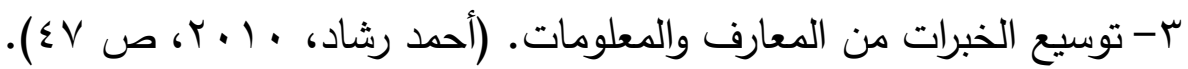
ع- تزويد الحصيلة اللغوية للتلميذ. 0- إعطاء كل حرف مكتوب الحجم المناسب له. (محمد فايز، 17 ــ ب، ص (0). 
ومن خلال ما سبق عرضه في هذا المحور يمكن استتباط مجموعة من مهارات القراءة والكتابة المناسبة لتلاميذ الموهوبين ذوي صعوبات التعلم، وأيضًا حاجة هؤلاء التلاميذ إلي تتمية بعض مهارات القراءة والكتابة من خلال استخدام البرنامج القائم علي الوعي الصوتي. المحور الثاني : مفهوه الوعي الصوتي، وأهميته ، ومهاراته ، ومستوياته ؛

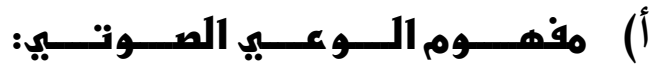

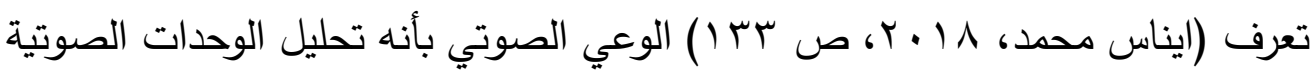

التي تتكون منها الكلمة أو تكوين كلمة من وحدات صسوتية مختلفة أو متشابهة، أو حذف أو

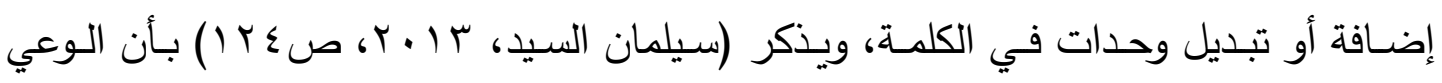
الصـوتي هو القدرة علي تحليل الأصـوات التي تتكون منها الكلمـة، ووضـحت (شفيقة أزادوه،

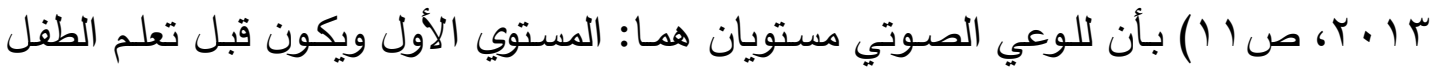
للقراءة، ويعتمد بشكل كلي علي المؤشرات الحسية للطفل، والمستوي الثاني ويظهر لدي الطفل بعد تمكنه من الرموز الأبجدية، كما يعرفه (Yeung,S.,2013,p9)، بأنه "القدرة على تعرف أصسوات الكلمات وإعـادة تركيبها، وهي مهارة قرائية يجب على التلميذ اكتسـابها ومن ثم فإن الوعي الصوتي يعد بمثابة فهم الأساليب المختلفة التي يمكن أن يقوم المتعلم بمقتضـاها بتجزئة اللغة إلى مكونات أصغر أو وحدات صوتية أصغر والتعامل معها.

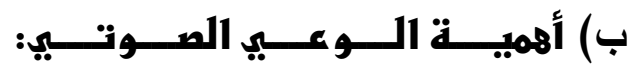
تتضـح أهميـة الوعي الصـوتي في أن تعليم القراءة للتلاميذ يتطلب معرفـة صـريحة بالجوانب الصوتية للكلام والتلميذ لكي يصبح قارئًا فاعلًا يتوجب عليه تعلم التطابقات المتتوعة بين الحروف وصورها الصوتية، كما أن الحاجة إلى الوعي الصوتي لا تتمثل في أهميته بالنسبة للقراءة فحسب، بل هو ضروري لتعلم التهجي، ولاكتساب مهارات الكتابة، والتلميذ الذي يكتسب مهارات الوعي الصوتي لن يكون بإمكانه أن يتعلم القراءة فقط بشكل صحيح، بل سيتمكن من

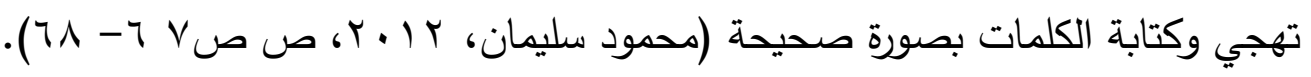
وقد أكد الكثير من الباحثين علي وجود علاقة بين الوعي الصوتي وتتميـة مهارات القراءة والكتابـة، وأن هذه العلاقة موجودة بصـرف النظر عن الوسيلة المستخدمة في معرفـة 


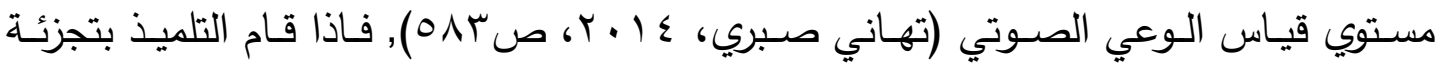
الكلمات إلى فونيمات مستقلة أو أن يستطيع أن يضم هذه الفونيمات معًا كي يتمكن من تكوين

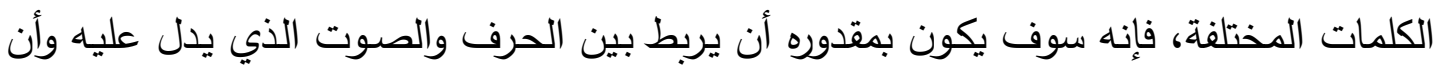

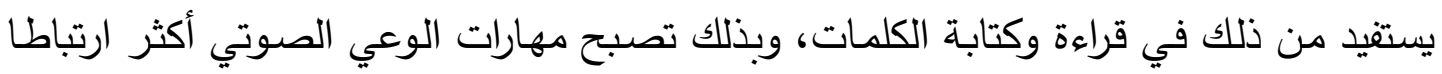
بالنمو القرائي والكتابي للتلاميذ. (Erdogan,O.,2011,p15)، وأيضا من المؤشرات الضرورية ولئية

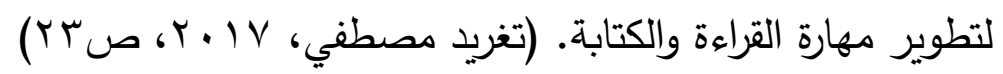

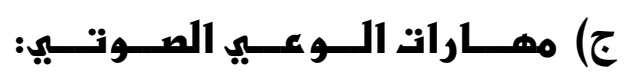

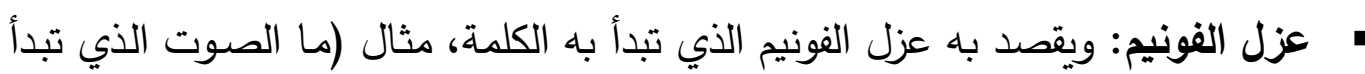

$$
\text { به كلمة باب، فتكون الإجابة (حرف الباء). }
$$

" ضم الفونيمات: ويعني ضم الفونيمات معا لتكون كلمة، (مثال) ما الكلمة التي تتكون

$$
\text { من أصوات (ش - م سم)، فتكون الإجابة كلمة (شمس). }
$$

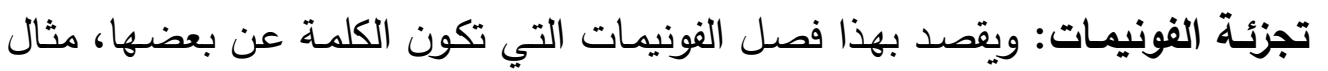

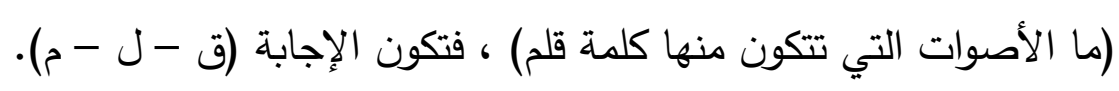

حذف الفونيم: أي نطق الكلمة بعد حذف صوت منها، مثال (كلمة فأر ، انطقها بدون

$$
\text { صوت الفاء، فتكون الإجابة (أر). }
$$

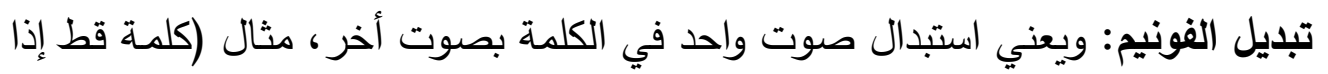

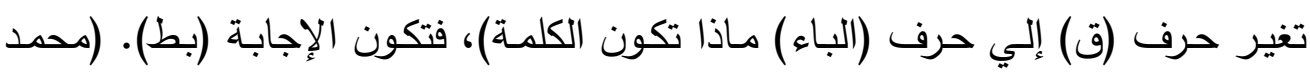

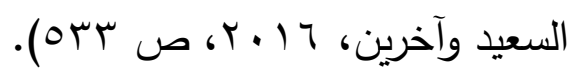

$$
\begin{aligned}
& \text { د) مستويات الوعي الصوتي: } \\
& \text { تتضمن مستويات الوعي الصوتي الآتي: }
\end{aligned}
$$

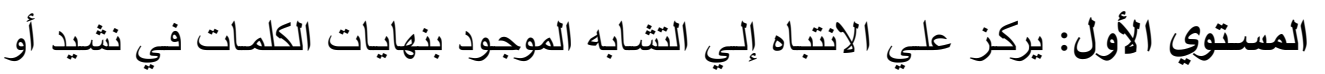

أغنية، ويطلق عليه اسم (التقفية)، وهو أقل المستويات تعقيداً.

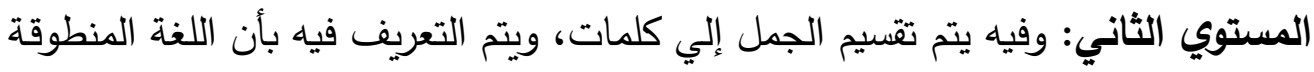

$$
\text { تتكون من كلمات منفردة. }
$$

المســتوي الثالــث: يستخدم أنثـطة تركـز علـي تقسـيم الكلمـات إلـي مقـاطع، وبنــاء

كلمات من مقاطع. 
" المستوي الرابع: يقدم هذا المستوي مجموعة من الأنشطة تهتم بالتشابهات والاختلافات

$$
\text { بين بدايات الكلمات ونهاياتها. }
$$

المستوي الخامس: يتم فيه التدريب علي مزج الفونيمات الفردية لتشكيل كلمات ومقاطع

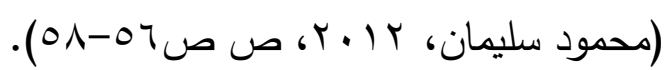

\section{هـ) علاقة تعليم القراءة والكتنابة بالو عي الصوتيى :}

يذكر ( Jonson,D.,2012 من خلال نتائج الدراسة الذي قام بها أن القراءة والكتابة

لا تقتصـر على كونها مهارة لتعلم الحروف وكتابتها وهجائها فقط بـل تمتد أهميتها لتشـل النـواحي الاجتماعيـة والاقتصـادية للفرد والمجتمـع، فـالفرد الـذي يعـاني مـن الضـعف القرائسي والكتابي سيواجه مشكلات في التحصيل الدراسي.، كما أشارت دراسـة (Berg,B.,2011) إلي أن إتقان تعلم مبادئ القراءة والكتابة يعطي في النهاية الأساس للقراءة والكتابة الناجحة، وهنالك دلائل تشير إلى أن استخدام أنشطة الوعي الصوتي تؤثر إيجابيًا في مخرجات الطلاقة القرائية والكتابية لدى التلاميذ الأقل تحصيلاً، وقد أكدت دراسة (Robinson,S.,2010)، أن التلاميذ الذين حصلوا على برنامج تدريبي قائم على الوعي الصوتي قد سجلوا معدلات أعلى فيما يخص مهارات الوعي الصـتي، والهجاء، والقراءة والكتابة مقارنـة بغيرهم الذين لم يحصلوا على هذا

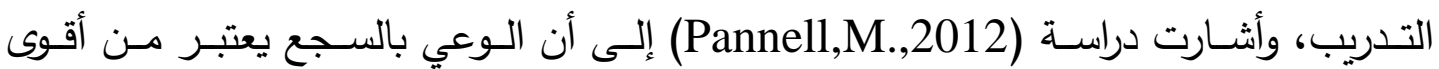
المؤشرات المبدئية للقدرة القرائية والكتابية فيما بعد، وذلك بعد اختبار مؤشرات النجاح القرائي والكتابي والتي تضــت الـوعي بالسـجع وتعـرف الحـروف وعلاقـة الحـرف بالصـوت ومفهوم الكلمـات، كمـا أوضـحت دراسـة (Buckstein,E.,2010) أن هنـاك دلائل قويـة تشير إلى أن مهارة الوعي بالسجع تلعب دورًا أساسيًا في نجاح عملية القراءة وبعدها الكتابة. ولتطوير الوعي الصوتي للتلاميذ الموهوبين ذوي صعوبات التعلم يجب الالتزام بالاتي: اولا:- تقديم مهارات الوعي الصوتي للتلاميذ علي شكل تدريب في الجانب الصوتي للغة بشكل عام وفي القراءة والتهجئة والكتابة بشكل خاص. ثانيا:- تهيئة التلاميذ لتمييز وإدراك الأصسوات الكلامية مبكراً وذلك عن طريق التدريب الجيد علي الكلمات والمقاطع، ثم التدريب علي الصوتيات، بواسطة المعلمين. ثالثا:- تعليم التلاميذ الحروف الهجائية وأسمائها، وذلك عن طريق تجزئة مقاطع الكلمات إلي

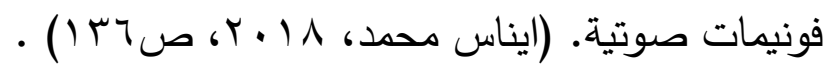


وقد اتضـح للباحثة من خـال العرض السـابق للمحور الثاني مجموعـة من المهارات التي

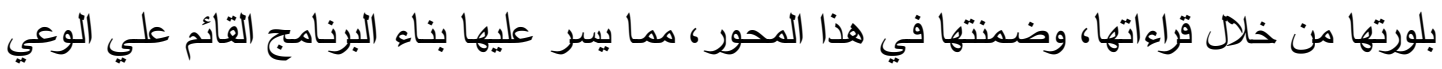

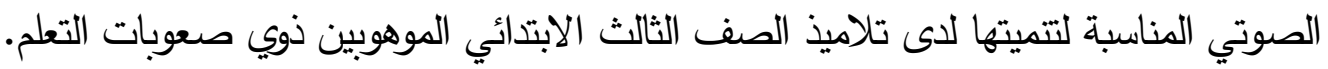

\section{المحور الثالث : مفهوه الموهوبين ذوي صعوبات التعلم وتصنيفهم وخصائصهم :}

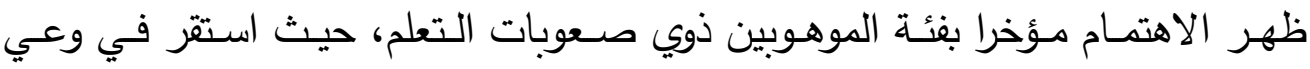
التربويين ان الموهوبين والعباقرة يحققون دائماً درجات مرتفعة علي اختبارات الذكاء والاختبارات

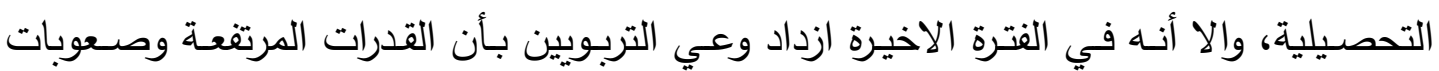

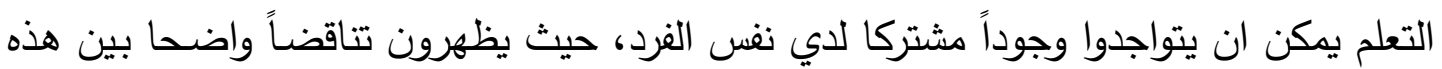

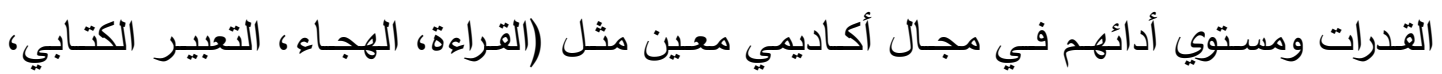

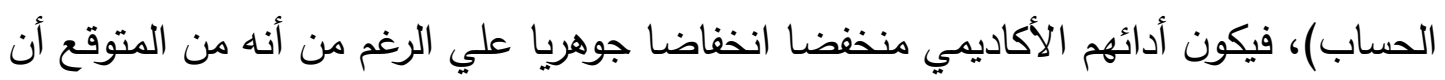

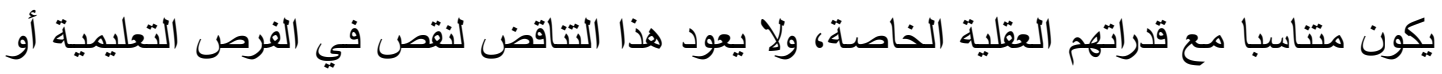

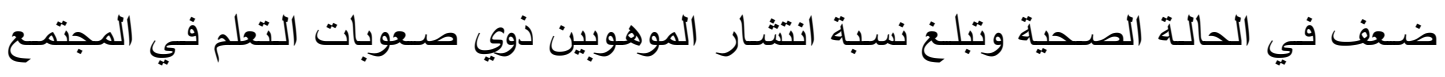

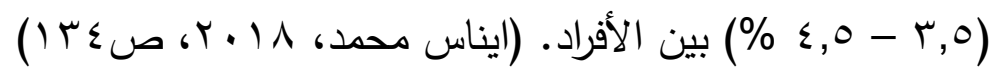

\section{أ) مفهوم الموهوبينز ذوي صعوبات التنعلمي:}

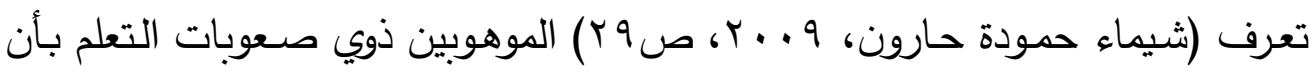

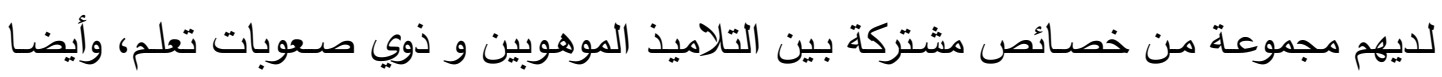

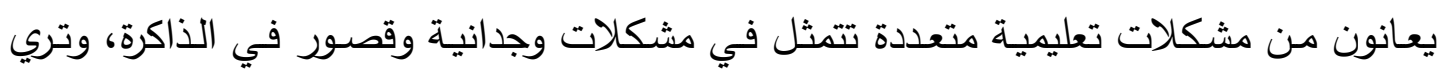

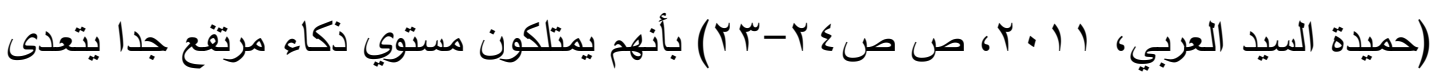

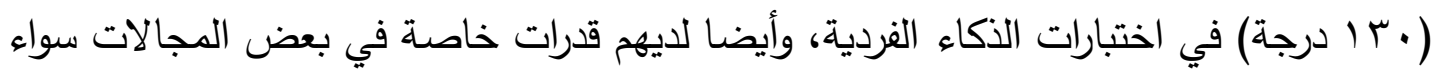

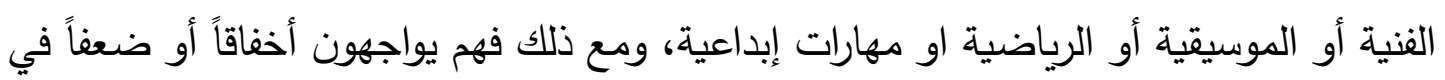

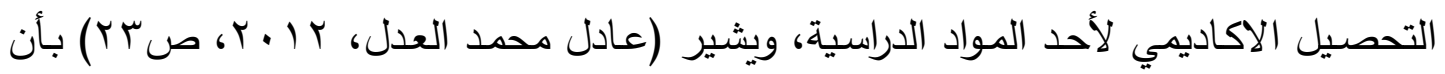

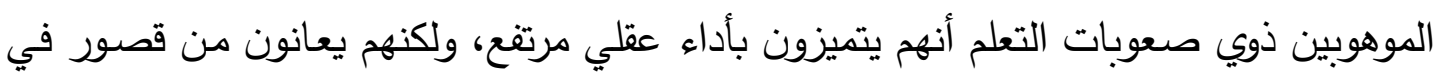

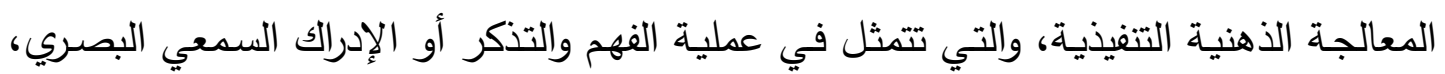

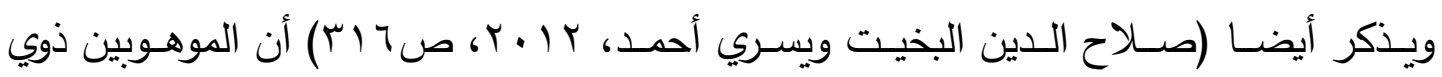

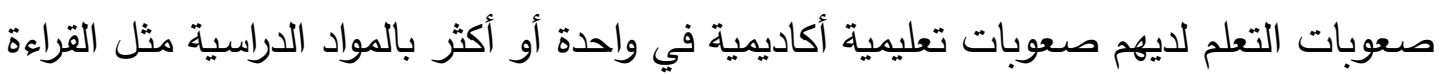
والكتابة وأيضا الحساب، رغم أنهم يحصلون علي أكثر من 90 \% في اختبارات الذيدة الذكاء. 


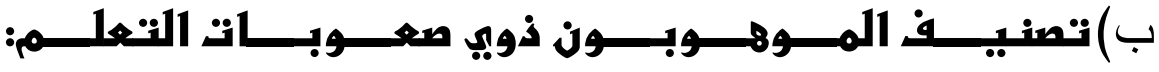

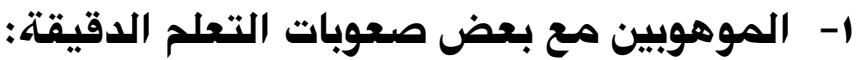

وهم يتميزون بارتفاع في مستوي ذكائهم أو تحصليهم الاكاديمي، مس وجود فجوة في أدائهم الفعلي والأداء المتوقع منهم، فقد نري بعض التلاميذ لديهم أداء مرتفع في القدرات اللغويـة والتعبيرية اللفظية، ولكنهم قد يعانون من صعوبات في القراءة والكتابة أو التهجئة وأيضـا رداءة

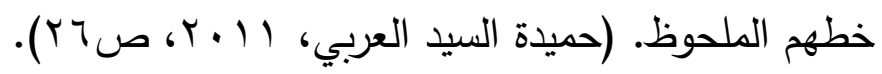
r- ثنائيو غير العاديتة المقنعت أو المطموستة: هم التلاميذ الذين يجمعون بين مظاهر الموهبة وصعوبات التعلم في آن واحد، ولكن تطغي واحدة علي الأخرى، فمظاهر الموهبة مثل الاستدلال والتفكير تطمس الصعوبات التي يعانونها، والعكس صحيح قد تطمس الصعوبات مظاهر الموهبة، وغالبا ما ينتظم هؤلاء التلاميذ

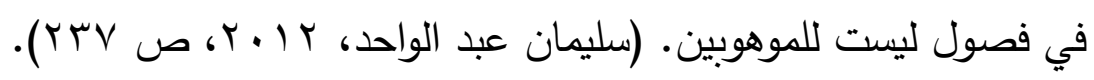

\section{r- - ذ ذوو صعوبات التعلم الموهوبين}

هم التلاميذ الذي تغلب عليهم صسوبات التعلم علي الموهبة، ويظهر هذا في تدني أدائهم في مختلف المواد الدراسية، ويتم الاهتمام بالصعوبات التي لديهم مـع إهمال الاستعدادات غير العادية التي يمتلكونها، ولذلك يحدث لهم تشتت وميل للانسحاب واحباط مـع انخفاض

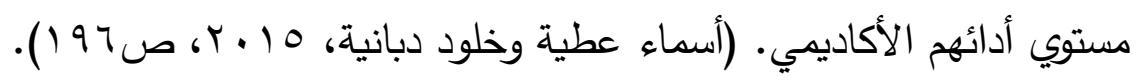

\section{ج) خصائم الموهوببن ذوي صعوبات التعلم:}

تعددت وتتوعت خصـائص الموهوبين ذوي صسوبات التعلم مـا بين جوانب أكاديمية أو معرفية، أو سلوكية، وتميزت بمجموعة من التناقضات الناتجة عن طبيعتها الاستثائية المزدوجة،

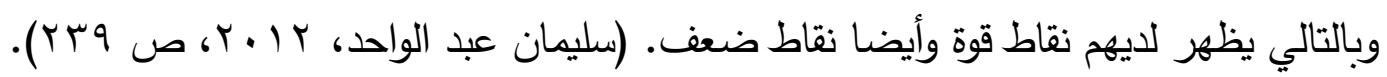
يتميز الموهوبون ذوو صعوبات التعلم بمجموعة من نقاط القوة والتي قد تختلف من فرد لآخر وهي كالتالي:

ثراء المفردات اللغويـة، توجد لديهم قدرة كبيرة علي فهم وتحليل العلاقات، القدرة علي الإدراك،، دقة الملاحظـة، الحدس، مهارة فائقة علي حل المشكلات، والتفكير المجرد، الإبداع، التميز في استخدام الذاكرة البصرية، تفوق في التفكير الرياضس، والمهارات

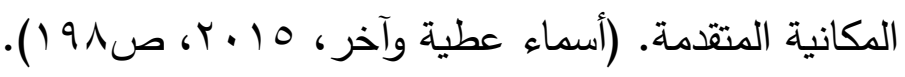


قدرة علي الاستبصار، حب القيادة واللباقة في التعامل، مهارات تواصل جيدة. إمكانية التفوق في الفنون والعلوم والمجالات التكنولوجية، سرعة التعلم، ذاكرة نشطة، مثابرة

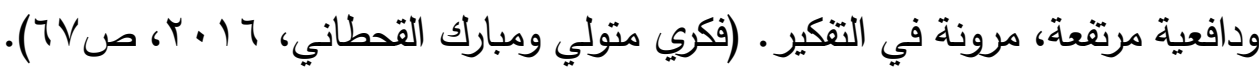
وتتمثل نقاط ضعف الموهوبين ذوي صعوبات التعلم في التالي: " صعوبات في التهجئة، والقراءة والكتابة، عدم التمييز بين الحروف المتثابهة، خط ردئ

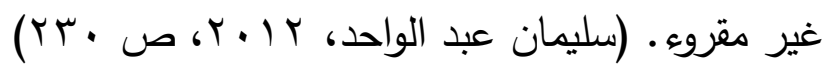
ضعف في الذاكرة قصيرة المدي، تتاقض بين قدراتهم الكامنة والإنجاز الفعلي، انخفاض في

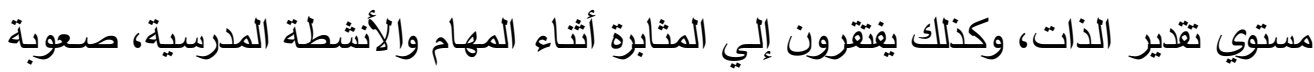

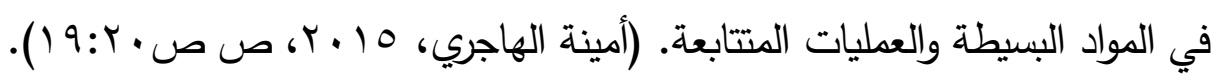

\section{التبــريبـي للــدراســة:}

لما كان الدراسة الحالية تستهف تتمية بعض مهارات القراءة والكتابة للتلاميذ الصف الثالث الابتدائي الموهوبين ذوي صعوبات التعلم، من خلال استخدام البرنامج القائم على الوعي

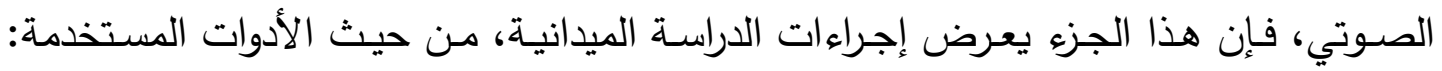
بنائها وتطبيقها، والأسـاليب الإحصـائية المستخدمة للحصـول على النتائج، ويتمثل الجانب

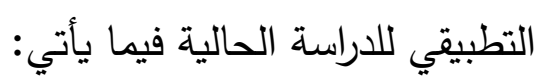

1- إعداد قائمـة مهارات القراءة اللازمـة للتلاميذ الصف الثالث الابتدائي الموهوبين ذوي

$$
\text { صعوبات التعلم. }
$$

ץ- إعـــاد اختبـار مهــارات القـراءة للتلاميـذ الصـف الثالــث الابتـدائي الموهـوبين ذوي

$$
\text { صعوبات التعلم. }
$$

r- إعداد بطاقة تقدير الأداء في مهارات النطق للتثلاميذ الصف الثالث الابتدائي الموهوبين

$$
\text { ذوي صعوبات التعلم. }
$$

ع - إعداد قائعة مهارات الكتابة المناسبة للتلاميذ الصف الثالث الابتدائي الموهوبين ذوي

$$
\text { صعوبات التعلم. }
$$

ه- إعـداد اختبـار مهـارات الكتابــة للتلاميـذ الصـــ الثالـث الابتــائي الموهـوبين ذوي

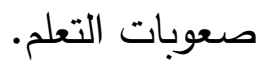


ج- بنـاء البرنامج التدريبي القائم على الوعي الصـوتي، ودليل المعلم (')-أداة معينـة- في

تتمية بعض مهارات القراءة والكتابة للتلاميذ الصف الثالث الابتدائي الموهوبين ذوي

$$
\text { صعوبات التعلم. }
$$

وفيما يلي تفصيل خطوات إعداد هذه الأدوات:

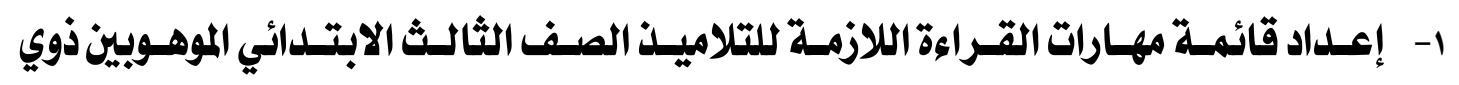

صعوبات التعلم: (r)

أ) تحديد الهـف من إعداد القائمـة: يهدف إعداد هذه القائمة إلى تحديد أهم مهارات القراءة اللازمة للتلاميذ الصف الثالث الابتدائي الموهوبين ذوي صعوبات التعلم، بعد عرضها على مجموعة من المتخصصين؛ حتى يتسنى تدريب التلاميذ عليها، وتنميتها لديهم من خلال

$$
\text { البرنامج التدريبي القائم علي الوعي الصوتي. }
$$

ب) مصادر بناء القائمة: تم الاعتماد على المصادر التالية عند بناء القائمة: نتائج الدراسات السابقة التي تناولت مهارات القراءة

دراسـة أهـداف تعلـيم القـراءة للتلاميـذ الصــف الثالــث الابتــــائي الموهـوبين ذوي

$$
\text { صعوبات التعلم. }
$$

دراسـة الأدبيات التربويـة المرتبطة بخصـائص تلاميذ المرحلة الابتدائية الموهوبين ذوي

$$
\text { صعوبات التعلم. }
$$

• • رأى الخبراء والمتخصصين.

ج) محاور القائمسة في صورتها الأولية: تم وضـع القائمسة في صورتها الأولية، وتكونت من ثـلاث مهارات رئيسـة خاصـة بالقراءة هـي: مهارات التعرف، ومهارات النطق، ومهارات

الفهم ويندرج تحت كل منها مجموعة من المهارات الفرعية الخاصة بها. د) صـدق القائمـة: بعد الانتهاء مـن إعداد القائمسة في صـورتها المبدئيـة، تم عرضـها على مجموعـة من الأسـاتذة المتخصصين في منـاهج وطرق تدريس ذوي الاحتياجـات الخاصـة واللغة العربية وذلك لإبداء الرأي حول صـلاحيتها لتحقيق الهدف من إعدادها، وإضـافة أو الو 
حذف أو تعديل ما يرونه مناسبًا لصلاحيتها للاستخدام، وقد قامت الباحثة بأجراء التعديلات التي اقترحها المحكمون بحيث إنها توصلت في النهاية إلي القائمة بشكلها النهائي.

\section{r- اختبار القراءة للتلاميذ الصف الثالث الابتدائي الموهوبين ذوي صعوبات التعلم: (1)} أ) تحديد الهاف من الاختبار: يهدف هذا الاختبار إلى قياس مدى تتمية بعض مهارات القراءة لاى تلاميذ الصف الثالث الابتدائي الموهوبين ذوي صعوبات التعلم، ومدى إلمامهم بمهارات القراءة المتضمنة بقائمة مهارات القراءة، والتي تم التوصل إليها في القائمة المعدة لذلك.

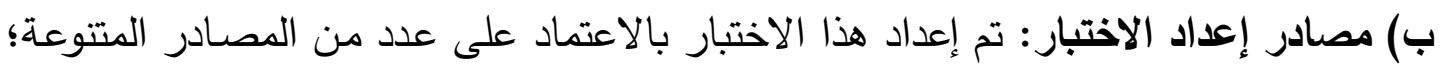
والتى تمثلت فيما يلى: هراسـة كتب القياس والتقويم التربوي، وكتابـات المتخصصين في إعداد الاختبـارات بأنواعها. دراسـة وتحليل أهداف تعليم القراءة للتلاميذ الصف الثالث الابتدائي الموهوبين ذوي

$$
\text { صعوبات التعلم. }
$$

دراسة وتحليل الدراسات والبحوث السابقة فى هذا المجال.

ج) مكونات الاختبار : يتكون الاختبار : من السؤال الأول ويتفرع منه (ع) أسئلة فرعية، والسؤال

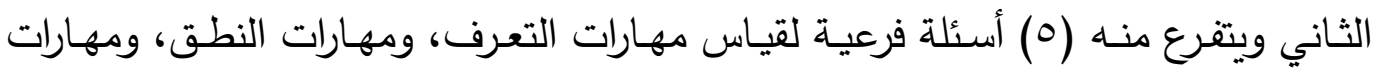

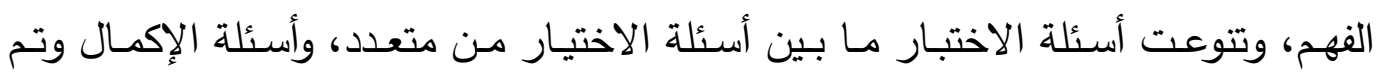

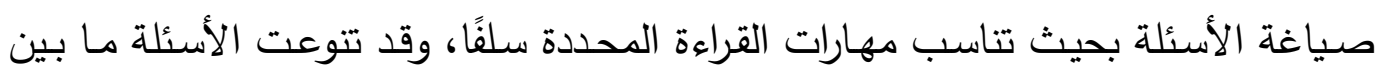
أسئلة الإكمال، وأسئلة الاختيار من متعدد. د) صدق الاختبار : بعد الانتهاء من إعداد الاختبار فى صورته الأولية، وصياغة تعليماته تم الإنمان عرضه على مجموعة من أساتذة المناهج وطرق التدريس التربية الخاصة واللغة العربية، لإبداء

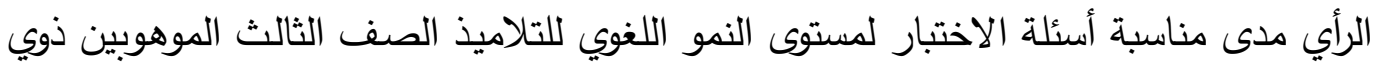

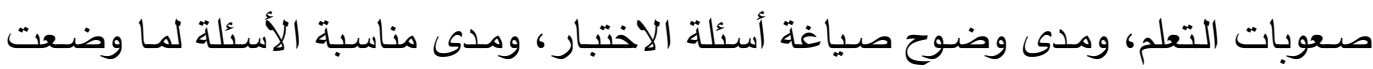
لقياسه، ومدى ارتباطها بالمهارات التي تم تحديدها، وقد أجمع المحكمون على مناسبة الأسئلة،

$$
\text { وقد أشاروا ببعض التعديلات التي تم الأخذ بها. }
$$


هـ) حساب ثبات الاختبار : يقصد بثبات الاختبار أن يعطى نفس النتائج إذا ما أعيد تطبيقه على

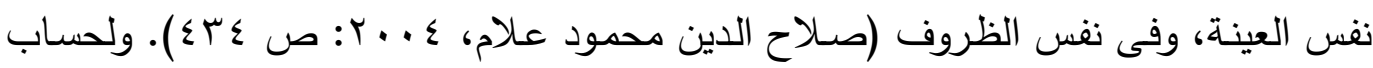

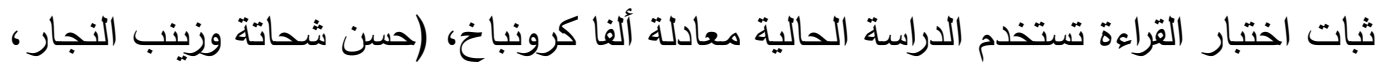

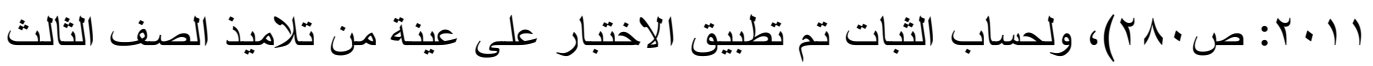
الابتدائي الموهوبين ذوي صسوبات التعلم وبلغت هذه العينـة (• ( ) تلميذا وتلميذة، وقد طبق الاختبار عليهم في الأسبوع الأول من شهر أبريل ^ا ــا، وبعد تطبيق الاختبار تم استخدام طريقـة الفـا كرونبـاخ وطريقـة التجزئـة النصـفية للتعـرف على مدى ثبـات الاختبـار وذلك باستخدام برنامج SPSS وكانت النتائج كما هو موضح في الجدول رقم (1) التالي: جلول رقمه ( ) ثبات اختبار مهارات القرائة

\begin{tabular}{|c|c|c|}
\hline التجزئة النصفية (معامل جيتمان) & الفا كرونباخ & الاختبار \\
\hline$\cdot, \wedge 00$ & $\cdot$, ATr & مهارات القراءة \\
\hline
\end{tabular}

من الجدول السـابق يُلاحظ ثبات اختباري القراءة والكتابـة جـاءت كبيرة بدرجـة كبيرة فجميعها أكبر من V, · وذلك في ألفا كرونباخ أو التجزئة النصفية.

ץ- بطاقة تقدير مهارات النطق للتلاميذ الصف الثالث الابتدائي الموهوبين ذوي صعوبات التعله (1) : أ) الهدف من إعداد البطاقة: تهدف إلى تقدير أداء تلاميذ الصف الثالث الابتدائي الموهوبين ذوي صعوبات التعلم في مهارات النطق، وذلك بعد ملاحظة قراءاتهم الجهرية لبعض الجمل المقدمة إليهم من خلال اختبار القراءة. ب) البطاقة في صورتها الأولية: اشتملت البطاقة علي أربع مهارات أساسية تم تحديدها وفق قائمة مهارات القراءة المناسبة للتلاميذ الصف الثالث الابتدائي الموهوبين ذوي صعوبات التعلم. ج) حساب صدق بطاقة تقدير مهارات النطق: صدق البطاقة: تم التأكد من صدق البطاقة بعرضها على مجموعة من المحكمين، وكانت نتيجة حساب صدق البطاقة أن نسبة 90\% من السادة المحكمين أجمعوا على أن مهارات النطق مناسبة لتقدير أداء للتلاميذ الصف الثالث الابتدائي الموهوبين ذوي صعوبات التعلم. 
د) حساب ثبات بطاقة تقدير مهارات النطق (القراءة الجهرية):

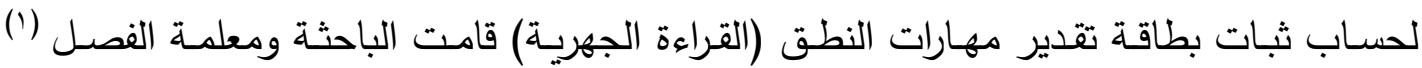

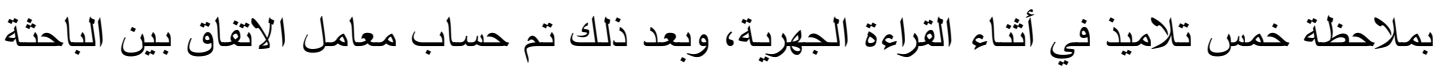

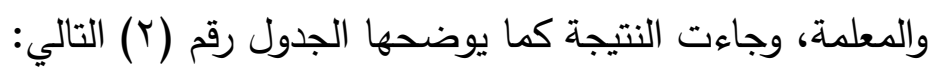

جدول (r) ثبات بطاقة تقدير الأداء في مهارات النطق (القراءة الجهرية)

\begin{tabular}{|c|c|c|c|c|}
\hline معامل الاتفاق (الثبات) & عدد البنود المختلف عليها & علد البنود المتفق عليها & علد البنود & التلميذ \\
\hline$\% 1 \cdots$ & --- & $\varepsilon$ & $\varepsilon$ & الأول \\
\hline$\% 1 \%$ & --- & $\varepsilon$ & $\varepsilon$ & الثاني \\
\hline$\% 1 \cdots$ & --- & $\varepsilon$ & $\varepsilon$ & الثالث \\
\hline$\%$ \% & 1 & $r$ & $\xi$ & الرابع \\
\hline$\%$ Yo & 1 & $r$ & $\xi$ & الخامس \\
\hline
\end{tabular}

يتضح من الجدول السابق أن معاملات الاتفاق (الثبات) أكبر من • ٪\%، وعلي هذا يكون الثبات مرتفعًا.

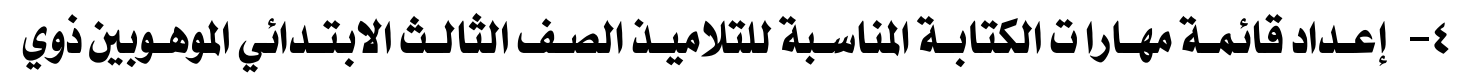
صعوبات التعله أ) تحديد الهـف من إعداد القائمة: يهدف إعداد هذه القائعة إلى تحديد أهم مهارات الكتابة المناسبة للتلاميذ الصف الثالث الابتدائي الموهوبين ذوي صعوبات التعلم، بعد اعدافي عرضها على مجموعة من المتخصصين؛ حتى يتسنى تدريب التلاميذ عليها، وتتميتها لديهم من دن الاني

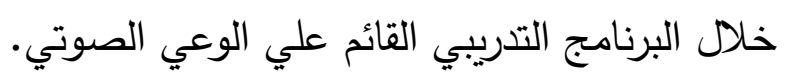

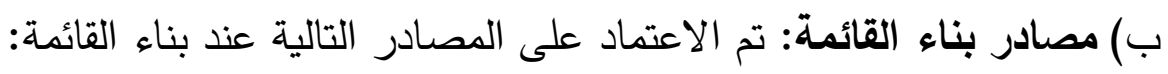
هتائج الدراسات السابقة التي تناولت مهارات الكتابة. هراسة أهداف تعليم الكتابة للتلاميذ الصف الثالث الابتدائي الموهوبين ذوي صعوبات هنات التعلم. هراسة الأدبيات التربوية المرتبطة بخصائص تلاميذ المرحلة الابتدائية الموهوبين ذوي دئي

$$
\text { • • أى الخبراء والمتخصصين. }
$$

( (1) وجهت الباحثة معلمة الفصل (الأستاذة/ صالحة سليم) إلى كيفية الملاحظة من خلال بطاقة تقدير الأداء

$$
\text { التي صمتها الباحثة. }
$$

(Y) ملحق رقم (T) قائمة مهارات الكتابة في صورتها النهائية. 
ج) محاور القائمة في صورتها الأولية: تم وضع القائمة في صورتها الأولية، وتكونت من

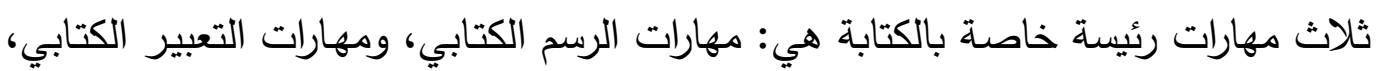
ومهارات جودة الكتابة، ويندرج تحت كل منها مجموعة من المهارات الفرعية الخاصة بها.

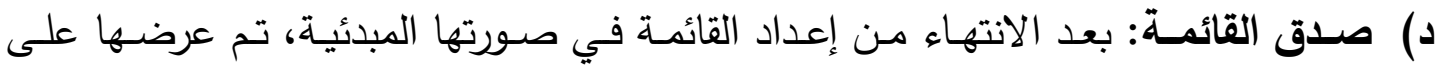

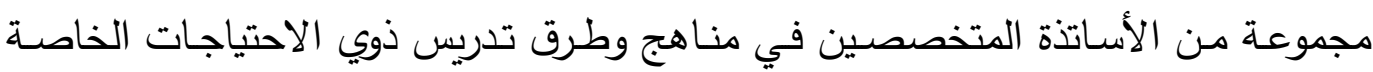
واللغة العربية وذلك لإبداء الرأي حول صـلاحيتها لتحقيق الهدف من إعدادها، وإضـافة أو لون حذف أو تعديل ما يرونه مناسبًا لصلاحيتها للاستخدام، وقد قامت الباحثة بأجراء التعديلات التي اقترحها المحكمون بحيث إنها توصلت في النهاية إلي القائمة بشكلها النهائي.

0- اختبار الكتابة للتلاميذ الصف الثالث الابتدائي الموهوبين ذوي صعوبات التعلم (1) : أ) تحيد الهاف من الاختبار: يهدف هذا الاختبار إلى قياس مدى تتمية بعض مهارات الكتابة لاى تلاميذ الصف الثالث الابتدائي الموهوبين ذوي صعوبات التعلم، ومدى إلمامهم بمهارات الكتابة المتضمنة بقائمة مهارات الكتابة، والتي تم التوصل إليها في القائمة المعدة لذلكك. ب) مصادر إعداد الاختبار: تم إعداد هذا الاختبار بالاعتماد على عدد من المصادر المتتوعة؛ والتي تمثلت فيما يلى: هراسة كتب القياس والتتويم التربوي، وكتابات المتخصصين في إعداد الاختبارات بأنواعها.

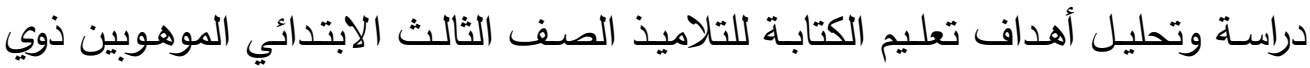

$$
\text { صعوبات التعلم. }
$$

دراسة وتحليل الدراسات والبحوث السابقة فى هذا المجال. ج) مكونات الاختبار: يتكون الاختبار من (r/ () سؤال لقياس مهارات الرسم الكتابي، ومهارات

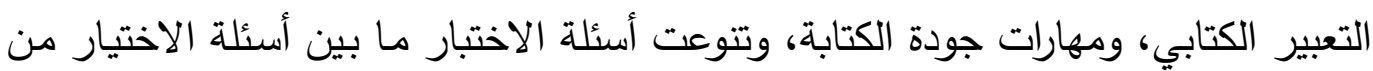
متعدد، وأسئلة الإكمال وتم صياغة الأسئلة بحيث تتاسب مهارات القراءة المحددة سلفًا، وقد الدابل

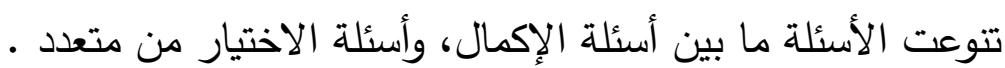

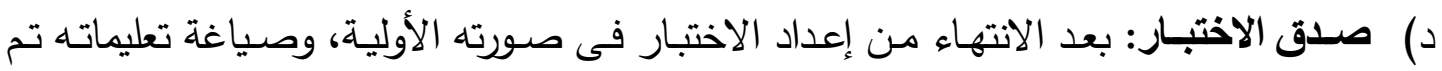
عرضه على مجموعة من أساتذة المناهج وطرق التدريس التربية الخاصة واللغة العربية، لإبداء 
الرأي في مدى مناسبة أسئلة الاختبار لمستوى النمو اللغوي للتلاميذ الصف الثالث الابتدائي الموهوبين ذوي صعوبات التعلم، ومدى وضوح صياغة أسئلة الاختبار ، ومدى مناسبة الأسئلة لما وضعت لقياسه، وقد أشار المحكمون بإجراء بعض التعديلات التي تم الأخذ بها.

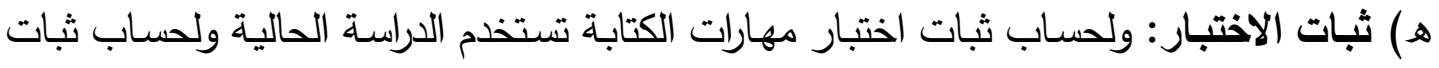

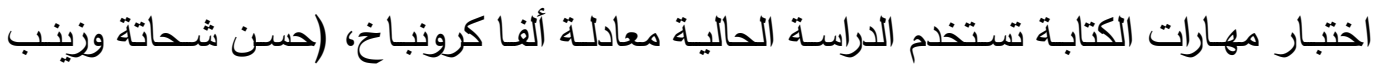

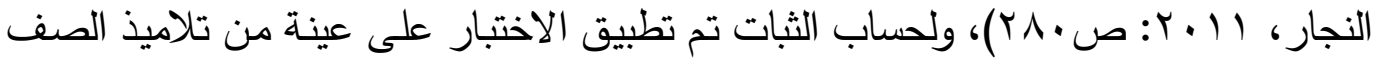

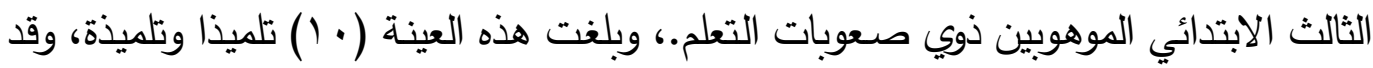

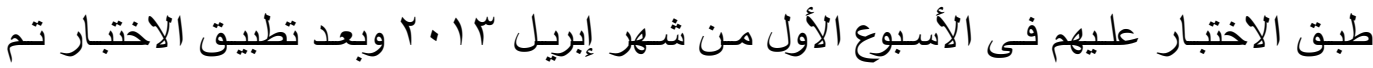

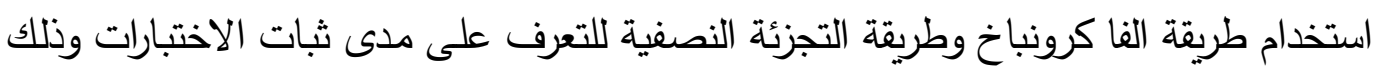
باستخدام برنامج SPSS وكانت النتائج كما هو موضح في الجدول رقم (r) التالي: جدول رقم (ץ) ثبات اختبار مهارات الكتابة

\begin{tabular}{|c|c|c|}
\hline التجزئية النصفية (معامل جيتمان) & الفاكرونباخ & الاختبـــــار \\
\hline -, val & • vir & مهارات الكتابة \\
\hline
\end{tabular}

من الجدول السابق يُلاحظ ثبات اختباري القراءة والكتابة جاءت كبيرة بدرجة كبيرة فجميعها أكبر من V, • وذلك في ألفا كرونباخ أو التجزئة النصفية.

\section{1- تصميه وإعداد البرنامج التلديبي القائم علي الوعي الصوتي وتطبيقه (1) :}

بعد تحديد مهارات القراءة والكتابة المناسبة للتلاميذ الصف الثالث الابتدائي الموهوبين

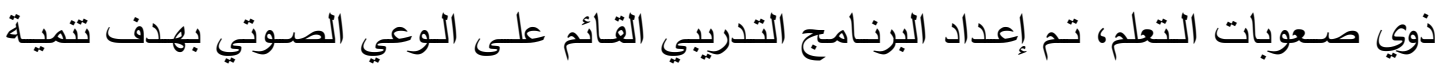

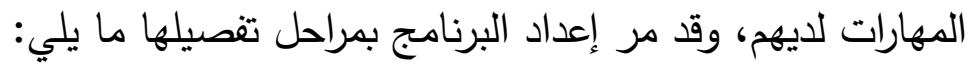

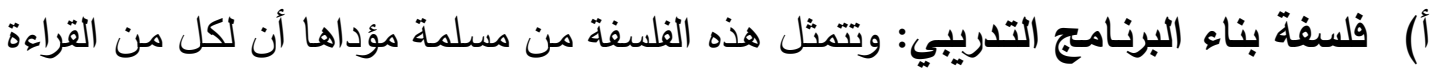

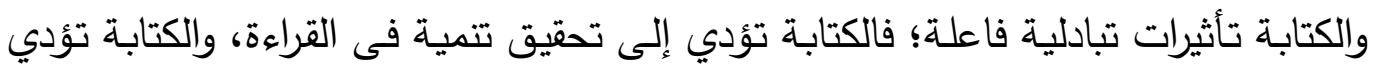
إلى تتمية فى القراءة، كما أن التدريب على الوعي الصوتي يؤدي إلى تتمية مهارات القراءة

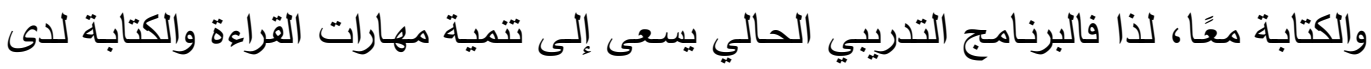

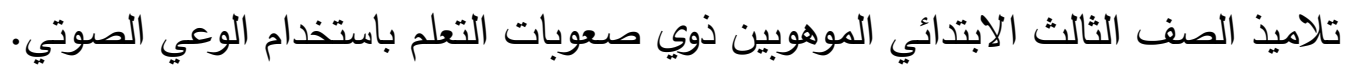


• الهدف العام: تتمية بعض مهارات القراءة والكتابة لدي تلاميذ الصف الثالث الابتدائي الموهوبين ذوي صعوبات التعلم باستخدام الوعي الصوتي. • الأهداف الإجرائية: بنهاية هذا البرنامج التدربي يتوقع أن يكون كل تلميذ/ تلميذة قادرًا على أن:

\begin{tabular}{|c|c|}
\hline يحلل الكلمة إلى مكوناتها أصوات /حروف. & يكتب كلمات من حروف معطاة. \\
\hline يكتب ما يملى عليه من كلمات بسرعة مناسبة. & يحدد مفهوم كل فقرة موضع التدريب. \\
\hline يكتب محاكيًا بعض الجمل بخط النسخ. & يملأ نموذجًا بخط واضح. \\
\hline يميز بين الحروف المتثابهة فى رسمها. & ينطق الكلمات دون حذف أو إضافة أو إبدال. \\
\hline يكتب مراعيًا المسافات المناسبة بين الحروف والكلمات & يكتـبـ الـــرف موضــع التـدريب فـي أول الكلـــة \\
\hline 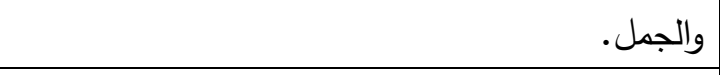 & ووسطها وآخرها. \\
\hline يتعرف حروف الدد (الألف-الياء - الواو). & ينطق أصوات الحروف العربية نطقًا صحيحًا. \\
\hline ينطق الجمل نطقً صحيحًا بدون حذف أو إضـافة أو & يتعرف رسم الحرف مع الحركات الثلاث من خلال \\
\hline إبدال. & 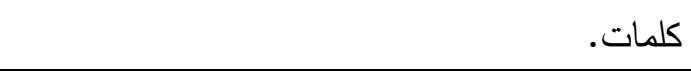 \\
\hline يفرق بين الكلمات المتشابهة والمختلفة في النطق. & يقسم الكلمة إلى أصواتها. \\
\hline يربط بين شكل الحرف وصوته. & ينطق الحرف موضع التدريب نطقًا صحيحًا. \\
\hline في مواضد الكلمـات المشتملة على الحرف موضـع التدريب & 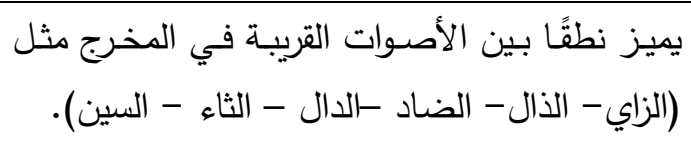 \\
\hline يتعرف الحرف موضع التدريب في الكلمات المكتوبة. & يتعرف الحرف موضع التدريب في الكلمات المنطوقة. \\
\hline
\end{tabular}

ج) تحديد محتوى البرنـامج: تم تحديد محتوى البرنامج التدربي في ضوء الأهداف الإجرائية السابقة، واستنادًا إلى ما تم التوصل إليه من خلال معطيات أدبيات الدراسة، وبما يتلاءم مع طبيعة فئة تلاميذ الصف الثالث الابتدائي الموهوبين ذوي صعوبات التعلم، وقد تم إعداد البرنامج التدريبي وفق ما يلي: - التي: • إعداد مجموعة من اوراق العمل بلـغ عددها (^) ثمانية أوراق وتتـاول كل ورقة عمل موضوعًا مختلفًا، كما أن كل ورقة عمل تتناول حرفًا من الحروف الهجائية، وهي على الترتيب: (ث- ذ-ش -ض -ط-ظ-ك-م)، كما لكل ورقة عمل أهداف خاصـة، ووسائل تعليمية ومجموعة كبيرة من التدربيات. 
د) اسـتراتيجية التدريس المستخدمة في البرنـامج : اعتمدت الباحثة في تطبيق البرنـامج التدريبي على مدخل التدريس التحليلي، وفيه يتم تعليم المفردات الجديدة جنبًا إلى جنب مـع حروف الهجاء، وتحليل الأصـوات في هذا المدخل يبدأ بالكلمـة ثم الدقاطع ثم البدايـة والوسط والنهاية. وقد استخدمت الباحثة هذا المدخل، وذلك لأنه:

ينمي مهارات تعرف الكلمات غير المألوفة لدى تلاميذ الصف يوظف الحروف داخل الكلمات المنطوقة. الثالث الابتدائي الموهوبين ذوي صعوبات التعلم

يمكن تلاميذ الصف الثالث الابتدائي الموهوبين ذوي صعوبات يعطي الفرصة لتعليم الهجاء بأنشطة متعددة. التعلم من تعلم الحروف الهجائية، وهذا يؤدي إلى تتمية مهارات القراءة والكتابة لديهم.

$$
\text { هـ أساليب التقويم المستخدمة: }
$$

• التقويم القبلي: وفيه تم تطبيق اختباري القراءة والكتابة؛ للوقوف على مستوى التلاميذ

$$
\text { (الضابطة والتجريبية) في مهارات القراءة والكتابة. }
$$

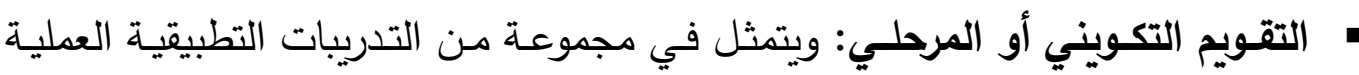

$$
\text { المتضمنة في البرنامج التدريبي القائع علي الوعي الصوتئي. }
$$

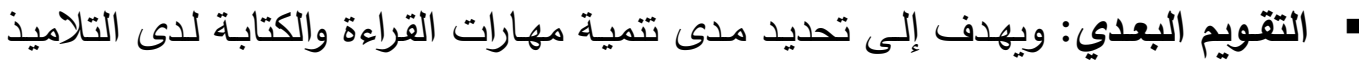

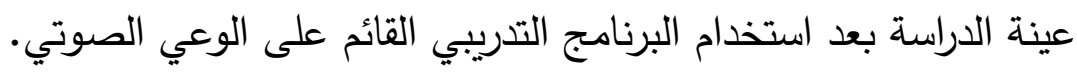
و) تطبيق تجربة الدراسة: مرت عملية تطبيق تجربة الدراسة بالخطوات التالية:

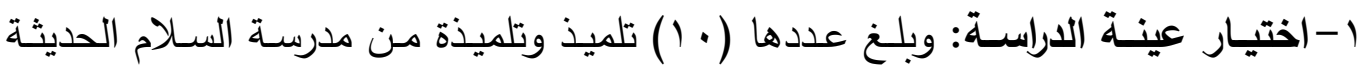
بمدينة المستقبل للضباط القوات المسلحة بمحافظة القاهرة. وتم تقسيمها إلى: مجموعة

$$
\text { واحدة تجريبية. }
$$

r-التطبيق القبلى لـ: اختبار القراءة والكتابة. تم تطبيق اختبار القراءة والكتابة قبليًا على

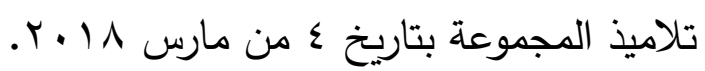

r-تطبيق البرنامج التدريبي القائم علي الوعي الصوتي على عينة البحث التجريبية، وبلغ

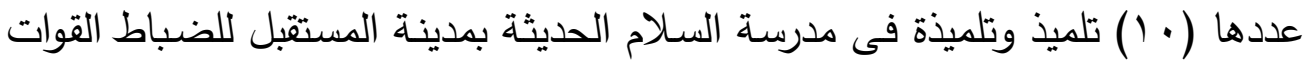

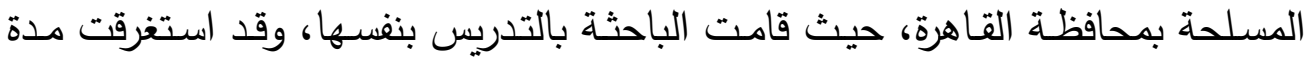
تطبيق البرنامج ستة أسابيع بمعدل مرتين كل أسبوع، بالإضافة إلى تخصيص أسبوع التبان 
كامل في نهاية البرنامج لإعطاء تغذية مرتدة تساعد التلاميذ لمراجعة جميع التدربات، وقد تم التطبيق البرنامج بداية من شهر مارس ^| ـ ب وحتي الأسبوع الأخير من شهر

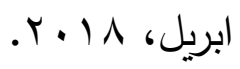

ع - التطبيق البعدي: بعد الانتهاء من تطبيق البرنامج التدربي، أعيد تطبيق أدوات الدراسة (اختبار القراءة والكتابة) تطبيقًا بعديًا؛ بهدف تعرف مدى تتمية مهارات القراءة والكتابة لدى تلاميذ الصف الثالث الابتدائي الموهوبين ذوي صعوبات التعلم عينة الدراسة.

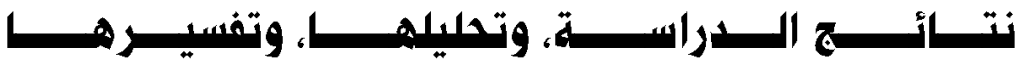
يهدف هذا المحور إلى: عرض النتائج التي أسفرت عنها الدراسة، والتحقق من صحة فروض الدراسة وتحليلها، وتفسيرها، وتقديم التوصيات والبحوث المقترحة.

\section{أولا : اختبار صحة فروض الدراسة والإجابة عن تساؤلاتها :}

\section{افنبار صمة الفرض الأول:}

بالنسبة للفرض الأول من فروض الاراسـة واللذي ينص على: توجد فروق ذات دلالية إحصائية بين متوسطى درجات تلاميذ المجموعة التجريبية فى التطبيقين القبلي والبعدي لاختبار مهارات القراءة ولاختبار مهارات الكتابة لصـالح التطبيق البعدي، لدراسـة الفروق بين متوسطي درجات التلاميذ في التطبيق القبلي والبعدي لاختبار مهارات القراءة والكتابة استخدت الباحثة اختبار ويلكوكسون (اختبار لابارامتري)، وذلك لأن حجم العينة اقل من •ب أي انه غير مناسب لتطبيق الاحصار البارامتري وقد جاءت النتائج كما يلي: جلول (§) نتائج اختبارويلكوكسون للداسة الفروق بين نتائج التلاميذ التطبيق القبلي والبعدي لاختبار مهارات القراءةوالكتابة

\begin{tabular}{|c|c|c|c|c|c|c|c|c|c|c|c|}
\hline الدلالة| & مستوى & $\mathbf{Z}$ & مجموع & متوسط & العلد & الـرتـب & الالمياري & المتوسط & العدد & التطبيق & مهارات \\
\hline \multirow[t]{2}{*}{ دالة } & $\cdot, \cdots 0$ & $r, A Y$. & - & - & - & الرتب السالبة | & $\cdot, 9 r Y$ & 1,0 & 1. & قبلي & \multirow{2}{*}{ |القراءة } \\
\hline & & & 00 & $0,0$. & 1. & الرتب الموجبة & $\cdot, v \cdot v$ & $1 \cdot, 0$. & 1. & بعدي & \\
\hline \multirow{2}{*}{ مستوى } & $\cdot, \cdot \bullet \xi$ & $r, \wedge \leqslant \wedge$ & - & - & - & الرتب السالبة & $\cdot, 071$ & $1,1 \cdot$ & 1. & قبلي & \multirow{2}{*}{ |لكتابة | } \\
\hline & & & 00 & $0,0$. & 1. & الرتب الموجبة & $\cdot, 799$ & $11, \xi \bullet$ & 1. & بعلي & \\
\hline
\end{tabular}


مـن الجدول رقم (乏) السـابق يُلاحظ وجود فروق ذات دلالـة إحصـائية بين درجـات

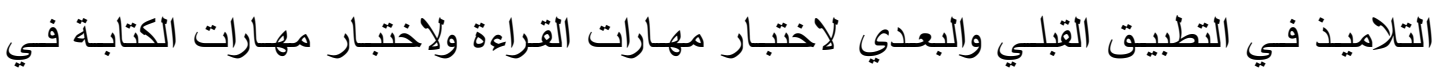
المجموع الكلي لجميع المهارات وذلك لصالح التطبيق البعدي، كما كان حجم الأثر كبيرً جداً

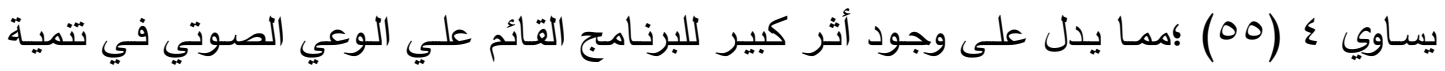
مهارات القراءة والكتابة للتلاميذ الصف الثالث الابتدائي الموهوبين ذوي صعوبات التعلم (عينة

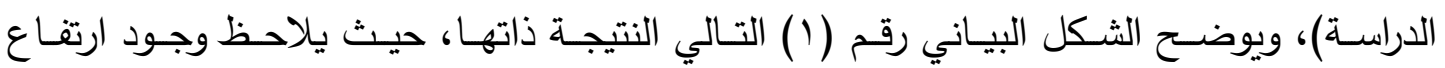
لمتوسطات درجات في التطبيق البعدي للمجموع الكلي لهذه المهارات.

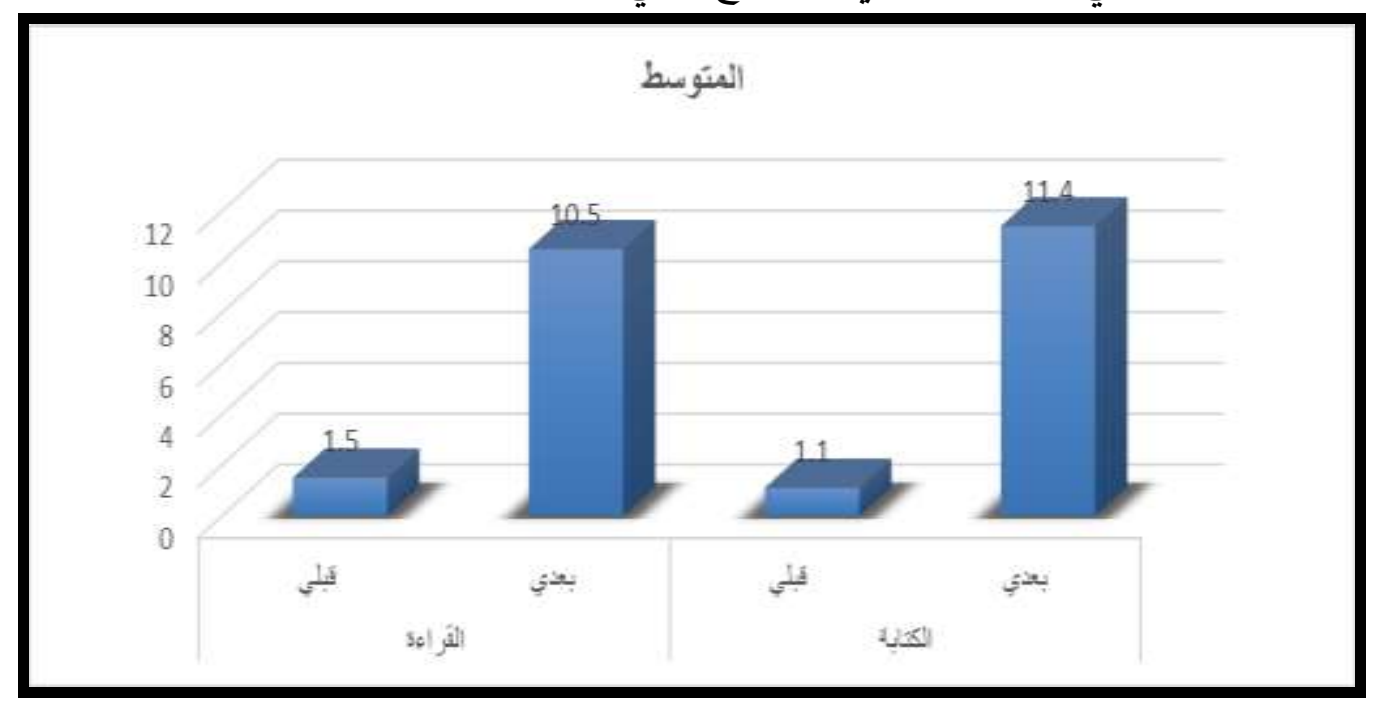

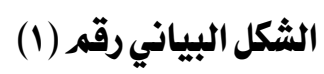

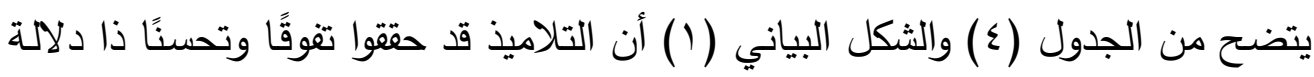

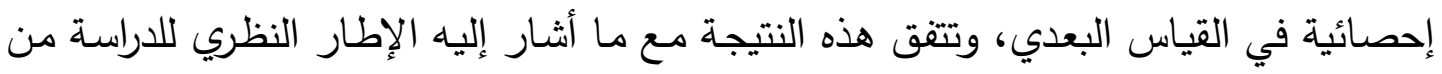

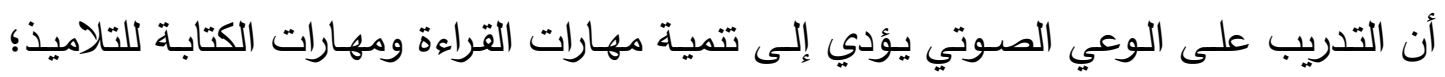

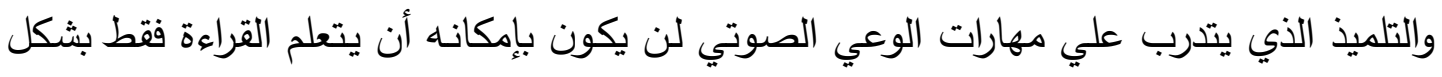

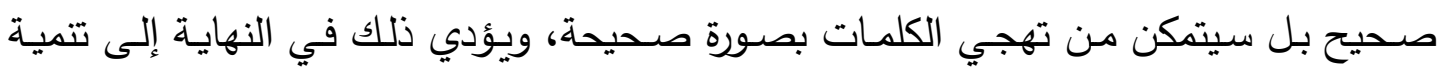
مهارات الكتابة أيضا، وتتفق هذه النتيجة مـع نتائج دراسات كل من (Erdogan, O., 2011) (Penke, M., 2009) مرتبطة بالوعي الصوتي قد أظهروا تحسنًا في القراءة والكتابة فيما بعد بالمقارنة بغيرهم الذين لم الم الماني

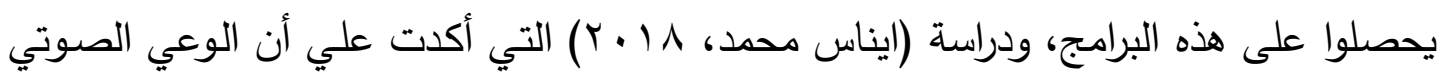

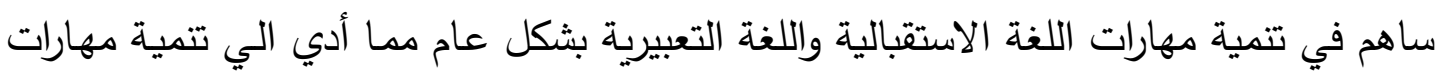


القراءة والكتابة والتهجئَة والإمـلاء، ودراسة (Yeung, S., 2013)، التي توصلت إلى أن

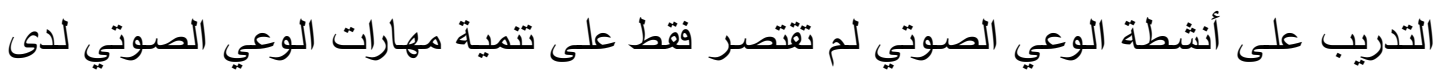

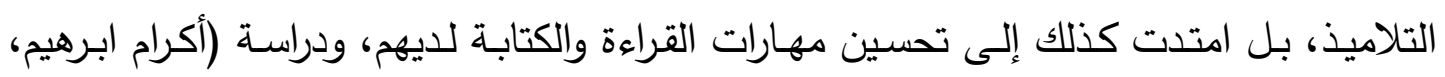

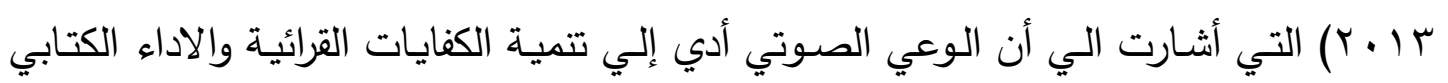
لاي المتعلمين المبتدئين. - الدئ.

\section{1فتبار صحة الفرض الثناني:}

بالنسبة للفرض الثاني من فروض الدراسة وإلذي ينص على: توجد فروق ذات دلالة

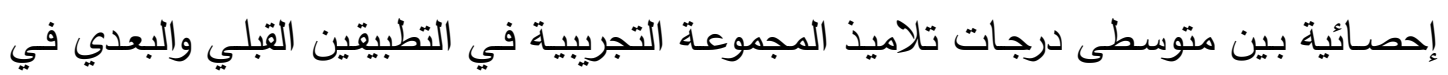
اختبار مهارات القراءة لصالح التطبيق البعدي، لدراسة الفروق بين متوسطي درجات التبات التلاميذ في التطبيق القبلي والبعدي لاختبار مهارات القراءة استخدمت الباحثة اختبار ويلكوكسون (اختبار

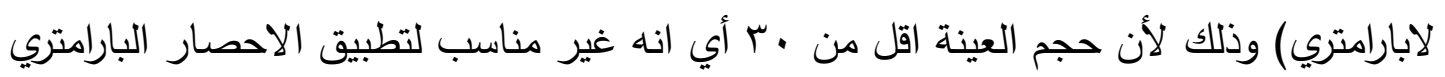

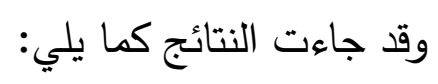

جلدول (0) نتائج اختبارويلكوكسوذ لدراسة الفروق بين نتائج التلاميذ

التطبيق القبلي والبعدي لاختبار مهارات القراءة

\begin{tabular}{|c|c|c|c|c|c|c|c|c|c|c|c|}
\hline الدلالة & مستوى & $\mathbf{Z}$ & الرتب مجموع & متوسط الرتب & العدد & الــرتــب & الالمياري & المتوسط & العدد & التطبيق & مهارات \\
\hline \multirow{6}{*}{ مستوى } & $\bullet, \cdot \bullet \xi$ & $r, \wedge 09$ & - & - & - & الرتب السالبة & •, OrV & $\cdot, 0$ & 1. & قبلي & \multirow{2}{*}{ التعرف } \\
\hline & & & $\Delta 0$ & $0,0$. & 1. & الرتب الموجبة & •,ZTr & $r, \Lambda$. & 1. & بعدي & \\
\hline & $\cdot, \cdot \bullet 0$ & r,ArT & - & - & - & الرتب السالبة & •, IAT & $\cdot, v$. & 1. & قبلي & \multirow{2}{*}{ الفهم } \\
\hline & & & 00 & $0,0$. & 1. & الرتب الموجبة & •, IAT & $\xi, \gamma$. & 1. & بعدي & \\
\hline & $\bullet, \cdot \bullet$ & $r, 919$ & - & - & - & الرتب السالبة & •, ¿AT & $\cdot, r \cdot$ & 1. & قبلي & \multirow{2}{*}{ النطق } \\
\hline & & & $\Delta 0$ & $0,0$. & 1. & الرتب الموجبة & - & $r$ & 1. & بعدي & \\
\hline
\end{tabular}

مـن الجدول رقم (0) السـابق يُلاحظ وجود فروق ذات دلالــة إحصـائية بين نتائج التلاميذ في التطبيق القبلي والبعدي لاختبا القراءة وذلك في جميع المهارات والمجموع الكلي

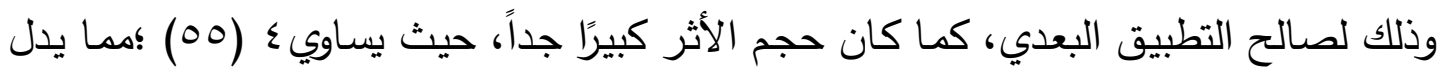

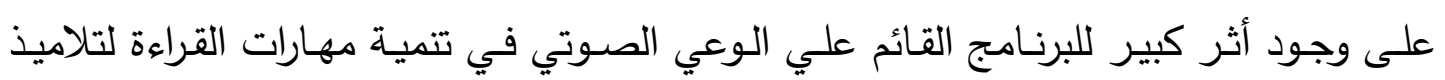
الصف الثالث الابتدائي الموهوبين ذوي صعوبات التعلم (عينة الدراسة)، ويوضح الثكل البياني 
رقم (r) التالي النتيجة ذاتها، حيث يلاحظ وجود ارتفاع لمتوسطات درجات التلاميذ في التطبيق البعدي لجميع المهارات الرئيسة والمجموع الكلي لهذه المهارات.

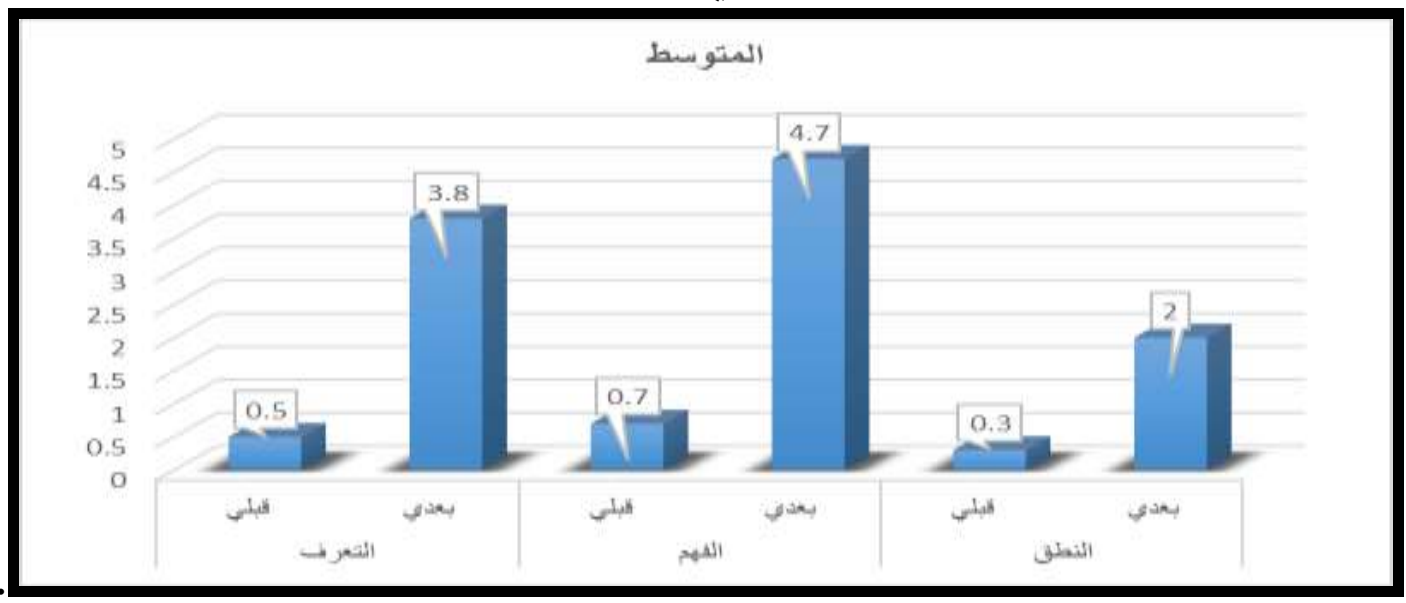

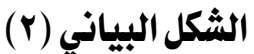

يتضح من الجدول (0) والثكل البياني (r) أن التلاميذ قد حققوا تفوقًا وتحسنًا ذا دلالمة

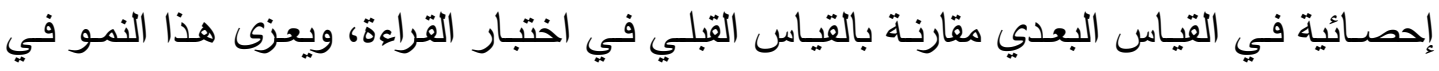

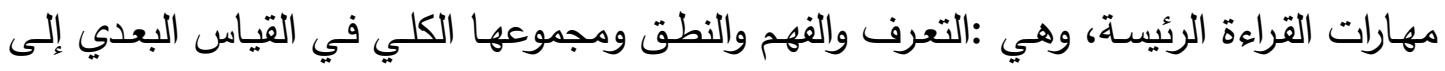

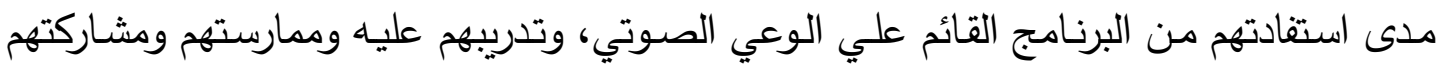

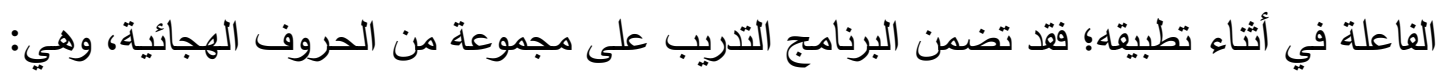

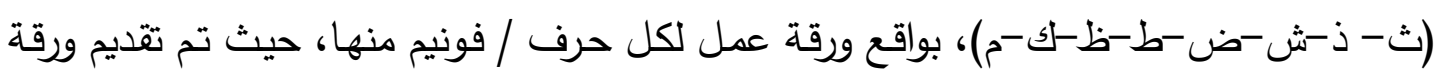
العمل في قالب أدبي، يبدأ بالاستماع إلى فقرة روعي فيها بساطة الجمل وسهولة الكلمات، وتكرار

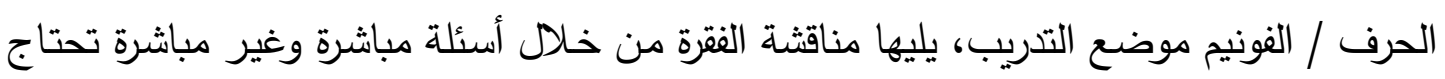

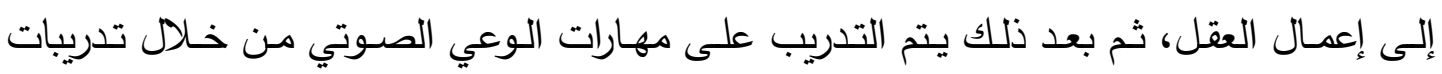

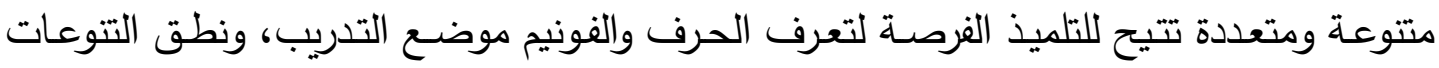

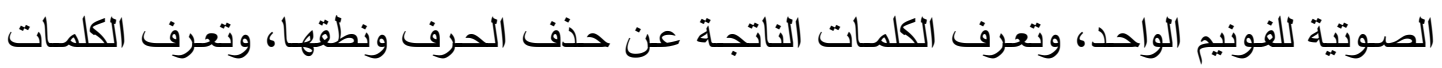
الناتجة عن إضافة الحرف ونطقها، ومزج الأصوات والمقاطع لتكوين كلمات، وتحليل الأصوات

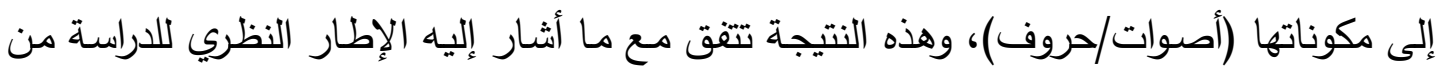

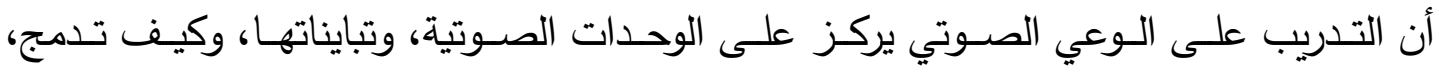
والاختلافات الناتجة عن تغيير الصوت الأول أو الأخير، أو الزيادات التي تطرأ على الكلمة، كل الكئل

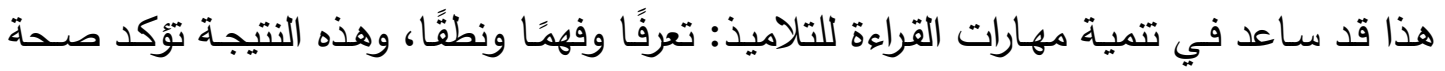


(Kardaleska, \& Karovska, الفرض الثاني، وتتفق هذه النتيجة مع نتائج دراسة كل من

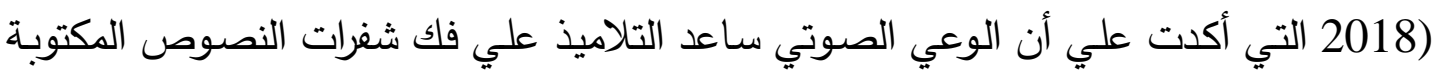

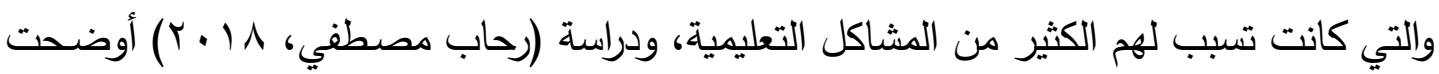
أن بعض مهارات الوعي الصوتي الأساسية ساعدت علي تعلم نطق الأصوات، مما ينطوي علي لئي

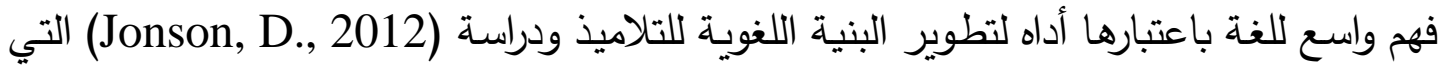

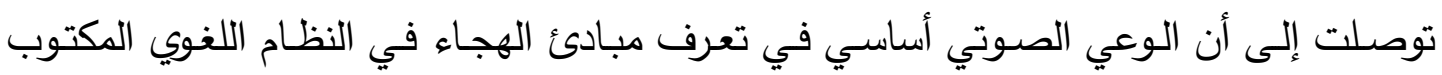

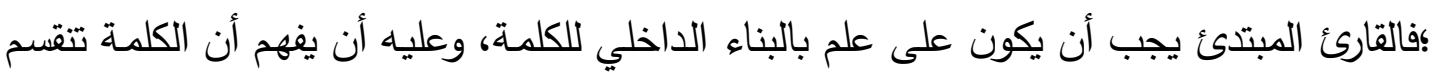

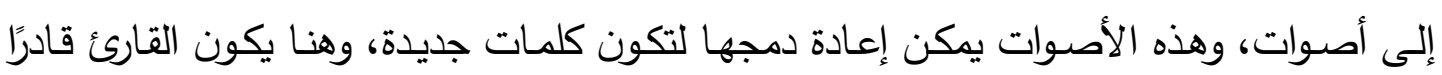

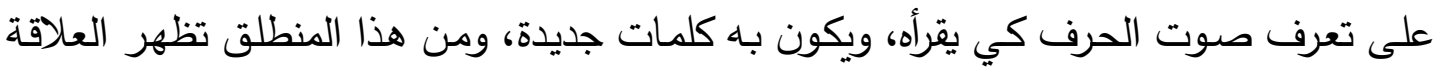
القوية بين القدرة على القراءة والوعي الصوتي كمؤشر لنجاح عملية القراءة فيما.

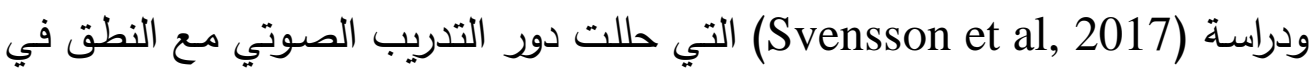
تعليم الاطفال وأظهرت النتائج تقدما كبيراً في مهارات القراءة والقدرة الصوتية، ودراسة (حفصة

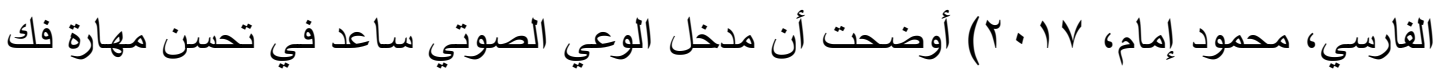

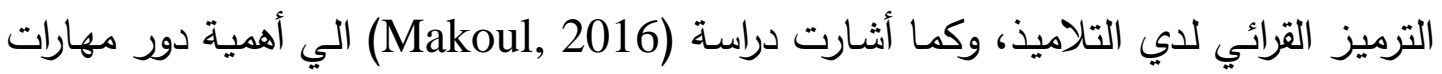

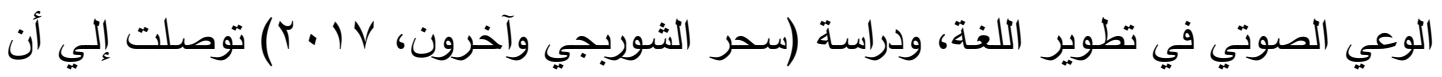

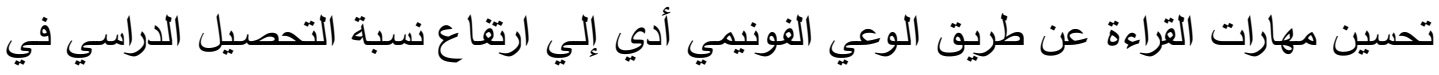

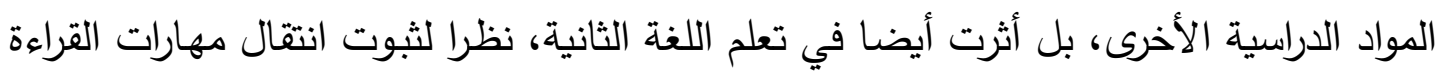

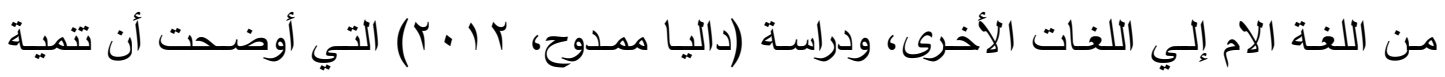

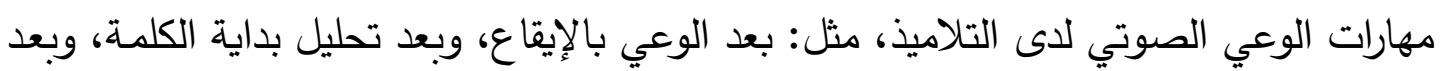

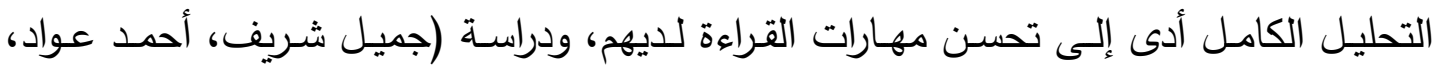

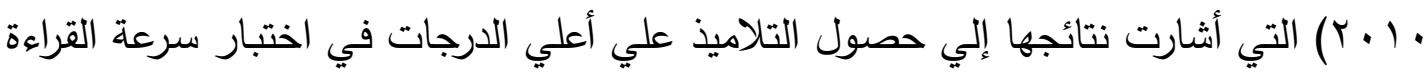

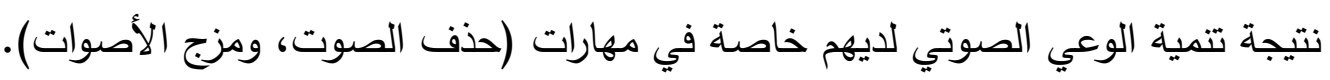

\section{اختبار صحة الفرض الثاني:}

بالنسبة للفرض الثاني من فروض الدراسة والذي ينص على: توجد فروق ذات دلالمة

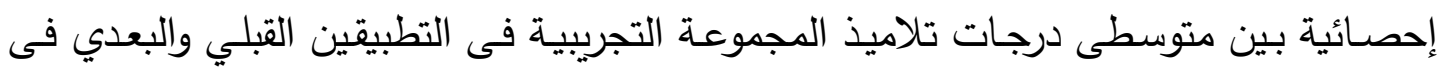
اختبار مهارات الكتابة لصالح التطبيق البعدي، لدراسة الفروق بين متوسطي درجات التلاميذ في 
التطبيق القبلي والبعدي لاختبار مهارات الكتابة استخدمت الباحثة اختبار ويلكوكسون (اختبار

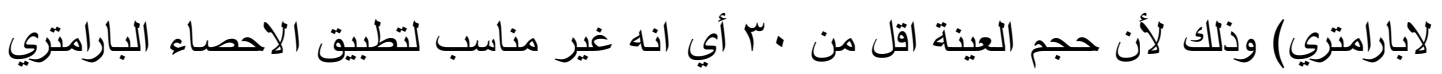

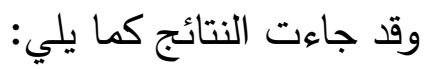
جدول (1) نتائج اختبار ويلكوكسون لدراسة الفروق بين نتائج التلاميذ التطبيق القبلي والبعدي لاختبار مهارات الكتابة

\begin{tabular}{|c|c|c|c|c|c|c|c|c|c|c|c|}
\hline الدلالة| & مستوى & $\mathbf{z}$ & مجمهوع & متوسط & العلد & الرتب & الالمعراف & المتوسط & العلد & التطبيق & مهارات \\
\hline \multirow{6}{*}{ مستوى } & $\cdot, \cdot \bullet \varepsilon$ & $r, q 1 r$ & - & - & • & الرتب السالبة & •, \{Aץ & $\cdot, r \cdot$ & 1. & قبلي & \multirow{2}{*}{ الكتابي } \\
\hline & & & 00 & $0,0$. & 1. & الرتب الموجبة & •, हrY & $r, \Lambda^{*}$ & 1. & بعدي & \\
\hline & $\cdot, \cdot \bullet \varepsilon$ & $r, A V Y$ & - & - & - & الرتب السالبة & $\cdot, 017$ & $\bullet, \xi \bullet$ & 1. & قبلي & \multirow{2}{*}{ الكتبيي } \\
\hline & & & 00 & $0,0$. & 1. & الرتب الموجبة & •, हrY & $\xi, \wedge \bullet$ & 1. & بعدي & \\
\hline & $\bullet, \cdot \bullet \xi$ & $r, A Y r$ & - & - & - & الرتب السالبة | & $\cdot, 017$ & •, \&• & 1. & قبلي & \multirow{2}{*}{ جوادة } \\
\hline & & & $\Delta 0$ & $0,0$. & 1. & الرتب الموجبة & •,ZTr & $r, \Lambda \cdot$ & 1. & بعدي & \\
\hline
\end{tabular}

من الجدول السابق يُلاحظ وجود فروق ذات دلالمة إحصائية بين نتائج التلاميذ في التطبيق القبلي والبعدي في اختبار مهارات الكتابة وذلك في جميع المهارات في المجموع الكلي داتي

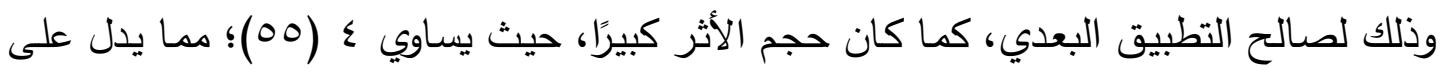

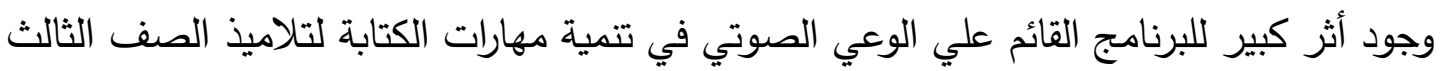

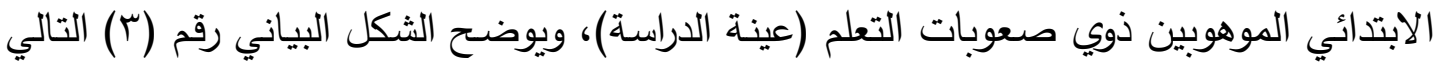

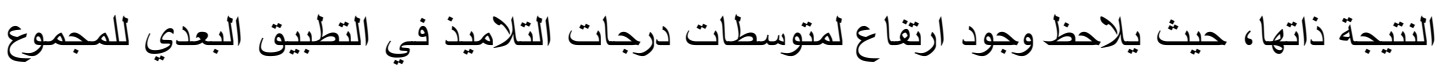

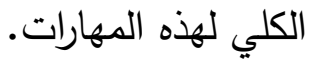

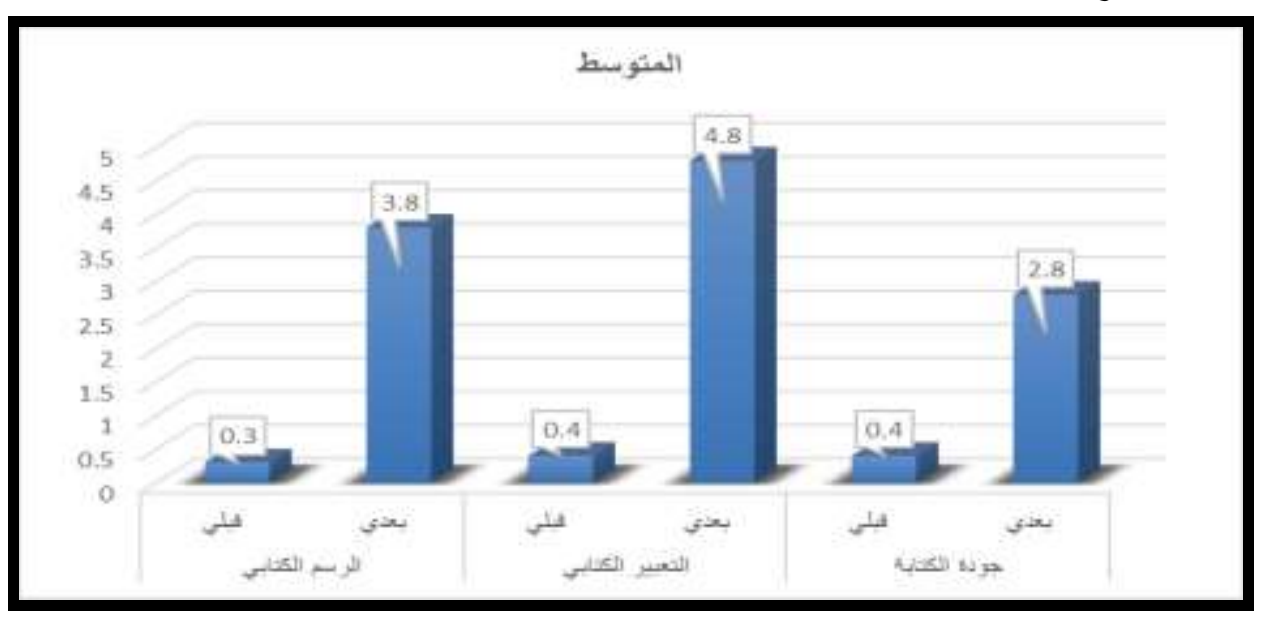

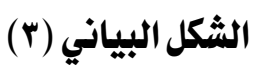


يتضح من الجدول (؟) والثكل البياني (r) أن التلاميذ قد حققوا تفوقًا وتحسنًا ذا دلالة

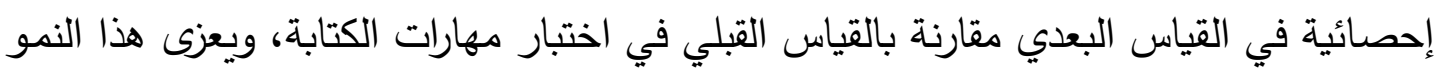

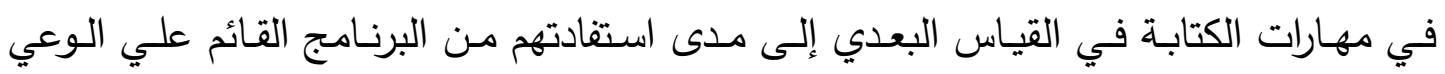

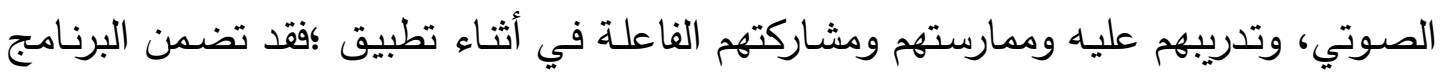

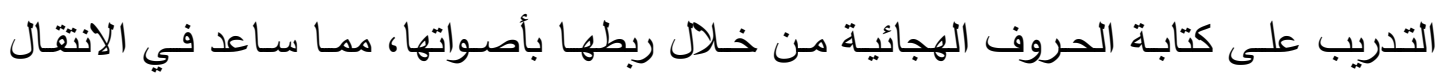

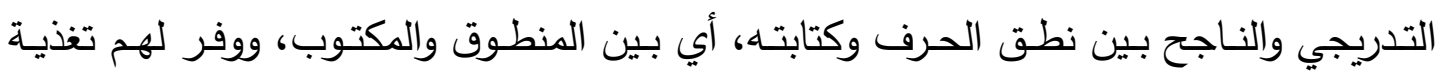

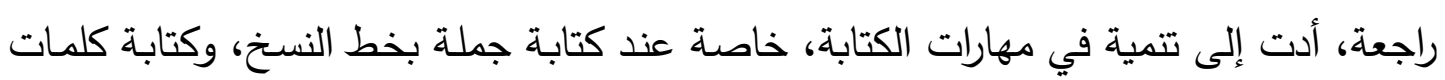

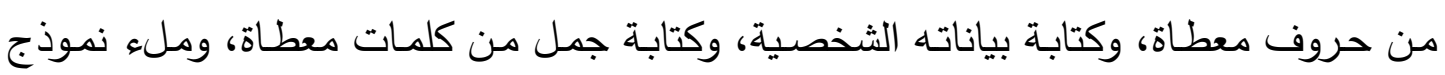

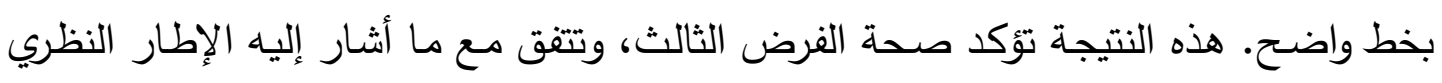

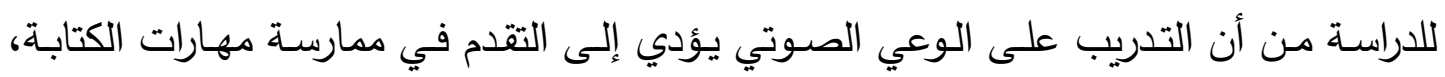

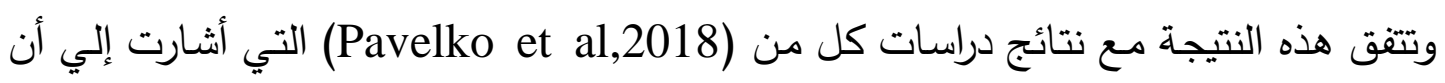
الوعي الصوتي ومعرفة الحروف وكتابة الاحرف قد ساعدت في تفسير العلاقة بين حالة اللغة داتة

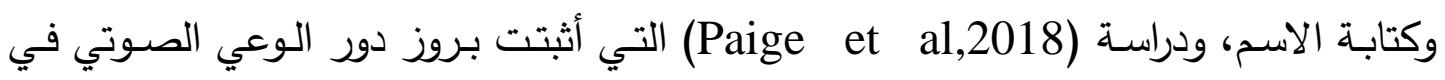

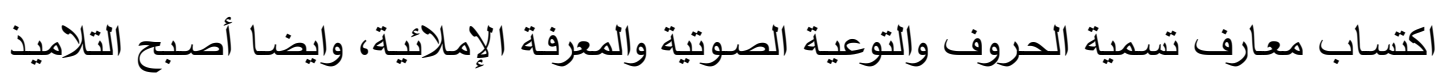

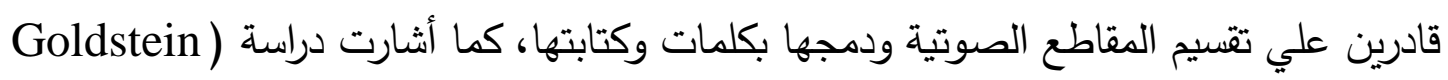
(et al,2017 إلي ايجابية مهارات الوعي الصوتي في حث استجابات التلاميذ بدعم تأثيرات التئية التغذية الراجعة التعليمية كاستراتيجية فعالة لنمذجة مهارات الأحرف الهجائية. وإلنتائج على النحو السابق تقود إلى عدد من التوصيات، وعداد من المقترحات يمكن

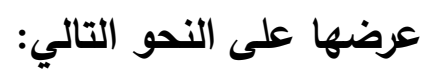

\section{ثانياً :التوصيات : في ضوء النتائج توصي الباحثة بما يلي:}

\section{في مجال التندريب:}

تدريب معلمي التلاميذ الموهوبين ذوي صسوبات التعلم على كيفية استخدام مهارات

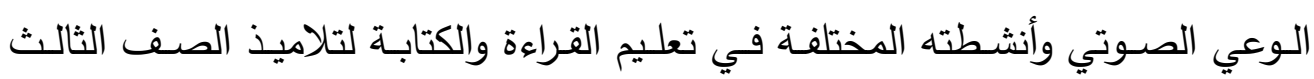
الابتدائي الموهوبين ذوي صعوبات التعلم.

تدريب تلاميذ الصف الثالث الابتدائي الموهوبين ذوي صعوبات دوبات التعلم على مهارات الوعي الصوتي اللازمة لهم وتتميتها لديهم قبل البدء في تعليمهم القراءة والكتابة. 


\section{في مجال تصميم مناهج الموهوبيز ذوي صعوبات التعلم وتطويرها:}

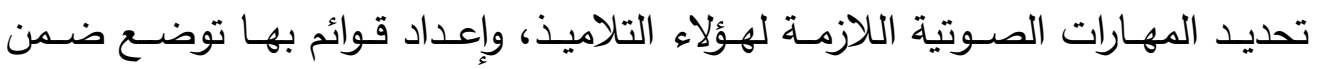

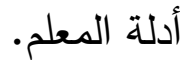

إعداد أدوات مقننة يستعين بها معلمو تعليم الكبار في تثخيص صعوبات القراءة لدى

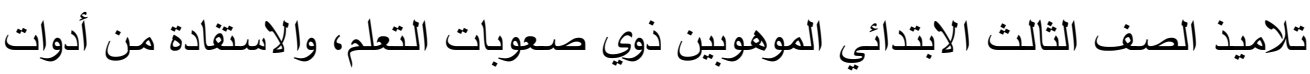
الداسة الحالية في إعداد أدوات مماثلة. الإفادة من نتائج الدراسة الحالية في تتفيذ برامج أخرى لتعليم بقية الحروف الهجائية بشكل يماثل ما تم إعداده في الدراسة الحالية.

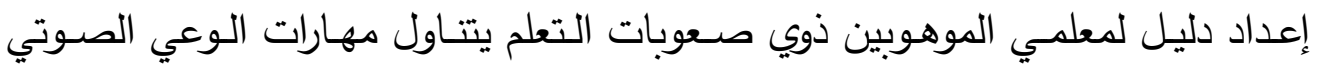
ومهارات القراءة والكتابـة، وكيفية التخطيط لها، ويعطي أمثلة توضيحية عن كيفية تدريسها وتتميتها لدى التلاميذ في ضوه دليل المعلم في الدراسة الحالية. ضرورة تضمين الوعي الصوتي ومهاراته في مناهج الموهوبين ذوي صعوبات التعلم. في مجال طرق التدريسر: إعادة النظر فيما يتعلق بتعليم القراءة والكتابـة للى تلاميذ الصف الثالث الابتدائي الموهوبين ذوي صعوبات التعلم، وتبني استراتيجيات حديثة ومتتوعة في تدريسها.

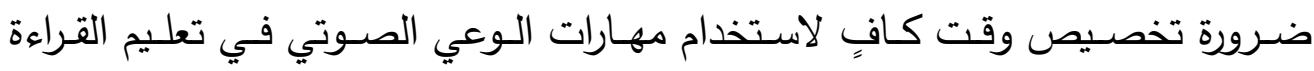

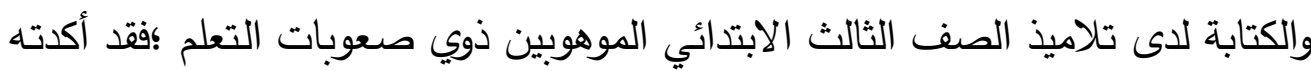
الدراسة الحالية، كما أكدته العديد من البحوث والدراسات السابقة.

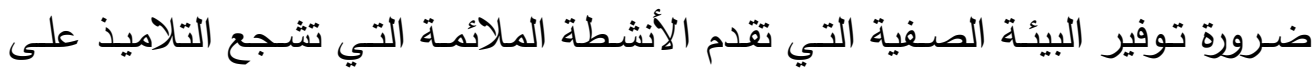
اكتساب مهارات الوعي الصوتي اللازمة لهم.

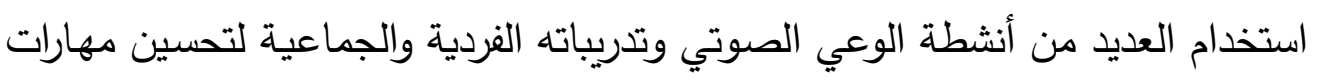

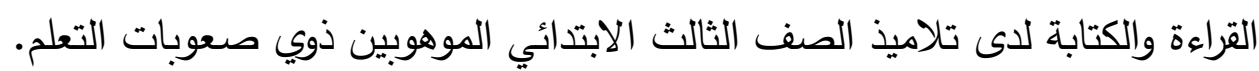
في مجال التنقويم:

توجيه نظر معلمي الموهوبين ذوي صعوبات إلى أن تقويم أداء تلاميذ الصف الثالث

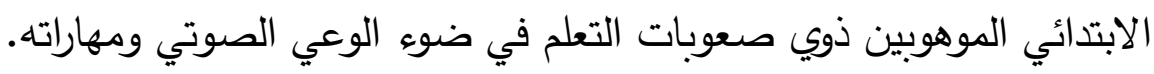


ضـرورة وجـود تقيـيم مستمر لأداء تلاميـذ الصـف الثالث الابتـائي الموهـوبين ذوي

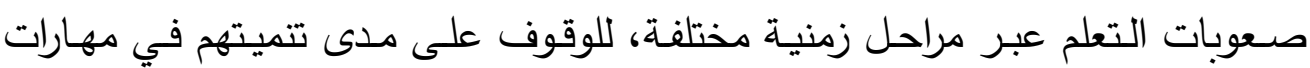
القراءة والكتابة.

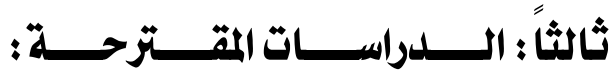

في ضوء ما أسفرت عنه الدراسة الحالية من نتائج، والتي تجعل منه نواة لبحوث أخرى ترتبط بالقراءة والكتابة، وتتمية مهاراتهما تقترح الباحثة ما يلي:

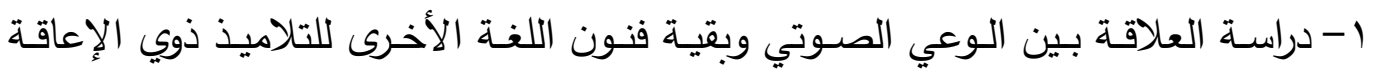
العقلية القابلين للتعلم.

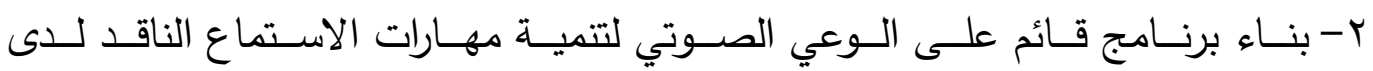
التلاميذ المكفوفين. ب- دراسة العلاقة بين الضعف في الفهم القرائي والتلاميذ ذوي صعوبات التعلم • 


\section{قـــائمســة المــــراجـعـع}

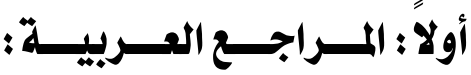

أحمد رشاد مصطفي: مستوي المهارات القرائية والكتابية لدي طلبة الصف السادس وعلاقته بتلاوة

وحفظ القران الكريم، رسالة ماجستير، كلية التربية، الجامعة الاسلامية، غزة، • 1 . . .

اسماء عطية، خلود دبانية: الاطفال الموهوبون ذوي صـوبات التعلم اكتثـاف تدخل ورعايـة تحديات وممارسـات، المؤتمر الدولي الثاني للموهوبين والمتفوقين، كليـة التربية، جامعـة

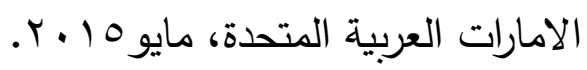

أكرم إبراهيم السيد: الـوعي الصـوتي وأثره في تحسين الكفايـات القرائيسة والأداء الكتابي لدى

الدارسين بفصول محو الأمية، مجلة القراءة والمعرفة، القاهرة، با ـ ب. ب.

أمـاني نـاوي، محمد شهرير : تقويم برنامج تفاعلي في تعليم التعبيرات الاصطلاحية في اللغـة العربية لدي الدراسين الناطقين بغيرهـا باستخدام برنـامج الوسـائط المتعددة، مجلة جامعـة

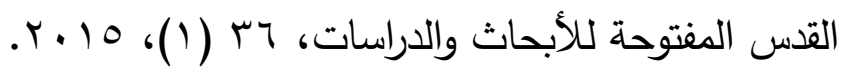

أمينـة الهرمسي الهاجري: بنـاء مقيـاس للكثف عن الموهوبين مـن ذوي التعلم من تلاميذ الحلقـة

الابتدائية في مملكة البحرين، مجلة العلوم التربوية والنفسية بالبحرين، عدد أ ( ( )، 10 ـ ب. آيات صـالح جمعـة: فاعلية برنامج تفاعلي محوسب في تحسين مهاراتي القراءة والكتابة لدي الطلبة من ذوي صعوبات التعلم النمائية في المرحلة الأساسية الدينا، رسالة ماجستير ، كلية

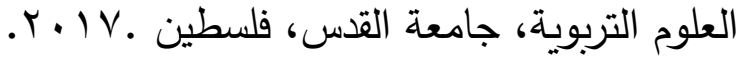

ايناس محمد عليمات: فاعلية برنامج تدريبي محوسب لتنمية مهارات الوعي الصوتي لتفعيل القدرة علي القراءة والكتابة لدي عينة من الطلبة الموهوبين من ذوي صعوبات التعلم، مجلة

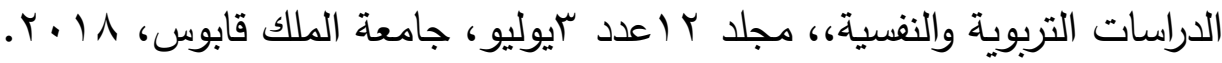
بركة محمد عوض: فاعلية برنامج محوسب لعلاج الضعف في بعض المهارات القرائية لدي تلاميذ الصف الرابع الأساسي، رسالة ماجستير، كلية التربية، الجامعة الإسلامية، غزة، r ا ـ r. تغريد مصطفي: أثر استراتيجية تعليمية قائمة علي نظرية منتسوري في مستوي الوعي الصوتي لدي الطلبة الصف الأول الاساسي في الاردن في ضـوء المستوي التعليمي لـلأم، مجلـة

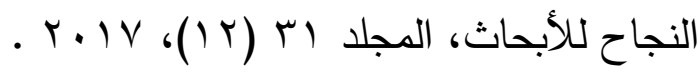


تهاني صبري كمال: برنامج تدريبي قائم علي تجهيز المعلومات لتتمية الوعي اللفظي والإخراج

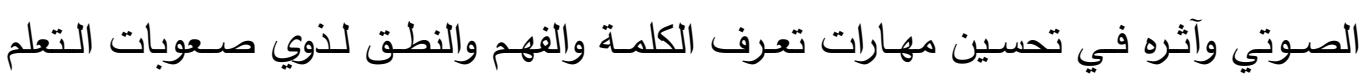
بالحلقة الأولي من التعليم الأساسي، معهد الدراسات التربوية، مجلة العلوم التربوية، العدد

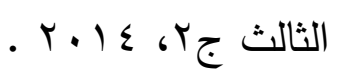

جميل شريف بابلي و أحمد عواد: فاعلية برنامج تدريبي في تتمية مهارات الوعي الصوتي وأثره

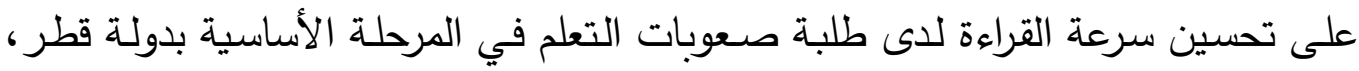

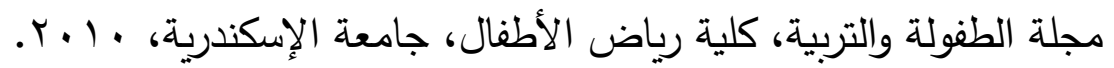
حفصة الفارسي، محمود إمام: فاعلية التدريب علي مهارات الوعي الصوتي في تحسين مهارة الترميز لدي التلاميذ من ذوي صعوبات القراءة، مجلة الدراسات التربويـة والنفسية، العدد

$$
\text { r. IV ، (1) }
$$

حميـة السيد العربي: فعاليـة برنـامج إرشـادي في خفض بعض الاضطرابات الاجتماعيـة

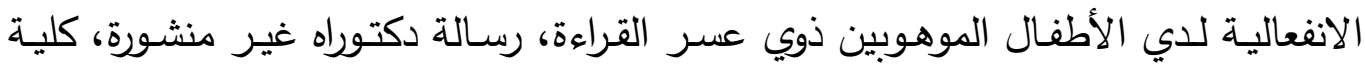

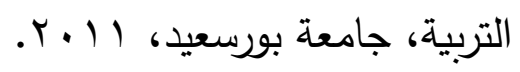

حنان مجدوبي: صعوبات تعلم القراءة بالتوافق الدراسي لاي تلاميذ السنة الخامسة ابتدائي، رسالة ماجستير ، كلية العلوم الاجتماعية، جامعة مولاي الطاهر ، 11 ـ ؟. داليا ممدوح كدواني: برنامج قائم على التحليل التطبيقي للسلوك لتتمية مهارات الوعي الصوتي للأطفال ذوي صـوبات التعلم المعرضين لخطر صعوبات التعلم، رسالة ماجستير غير

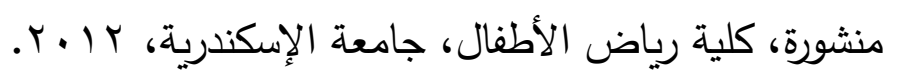
رحـاب مصطفي: فعاليـة برنـامج مقترح لتنميـة الوعي الصـوتي لدي تلميذات الصـف الأول

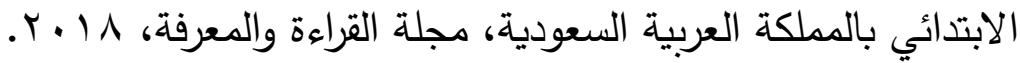
زهير عمراني: ماهية عسر الكتابة بين صعوبات التعلم النمائية : دراسة ميدانية لتلاميذ الصف

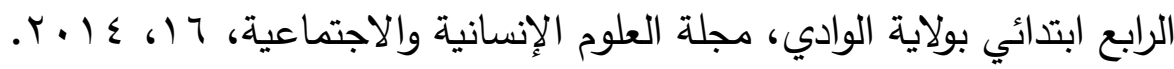
زيـن كامل الخويسكي: المهارات اللغويـة (الاستماع-التحدث-القراءة-الكتابـة)، دار المعرفـة

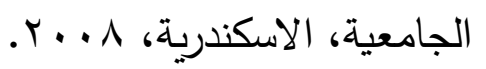


ســر الثـوربجي وآخـرون: فاعليـة برنـامج قـائم علـي التـدريس باسـتخدام الـوعي الفـونيمي

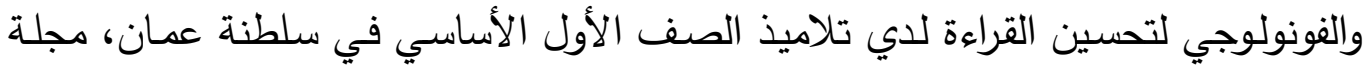

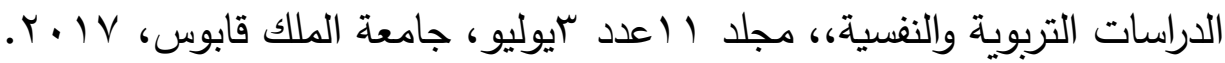

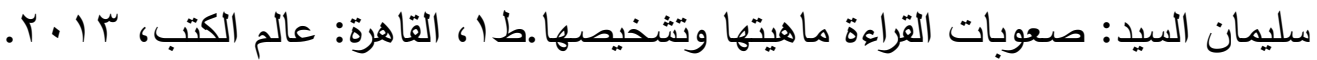

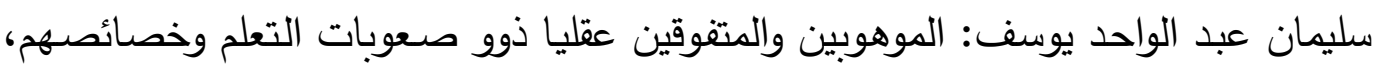

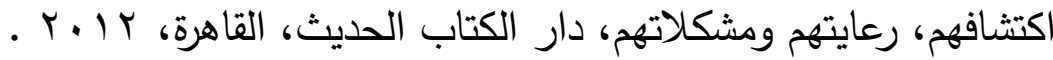
سومية قدي : صعوبات تعلم القراءة وعلاقتها بظهور الانسحاب الاجتماعي لدي تلاميذ المرحلة

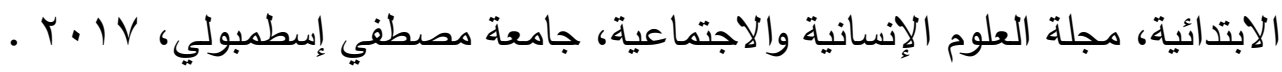

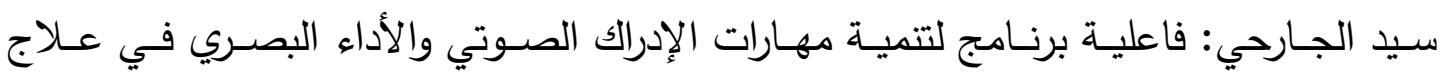

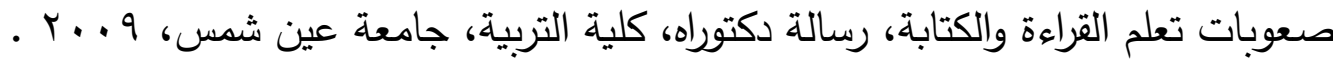

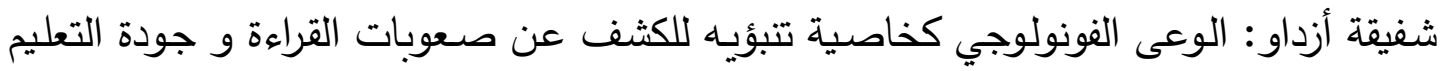

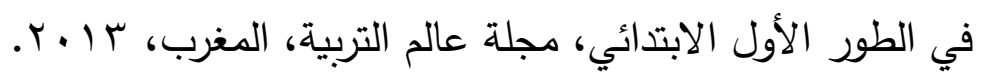
شيماء حمودة حارون: المتفوقون عقليا ذوو صعوبات التعلم في مدارسنا تنميتهم وجدانياً وعلمياً الإنها

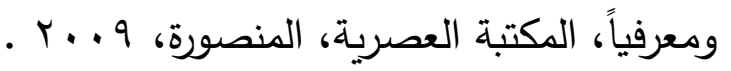

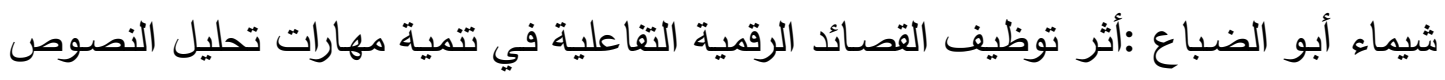
الأدبية لدي طالبات الصف التاسع الأساسي بغزة، رسالة ماجستير ، الجامعة الإسـلامية،

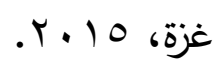

صلاح الدين فرح البخيت، يسري أحمد عيسي: دراسة مسحية للكثف عن الأطفال الموهوبين

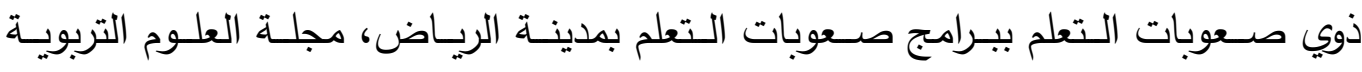

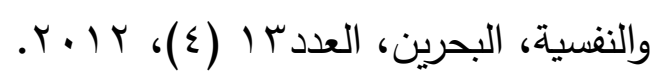

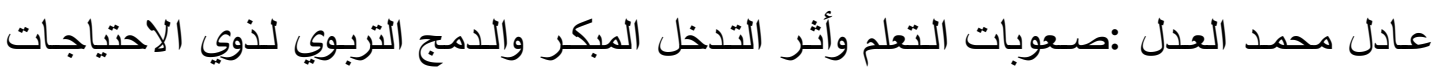

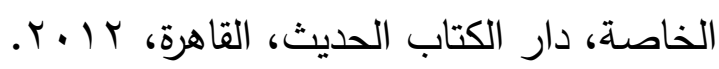

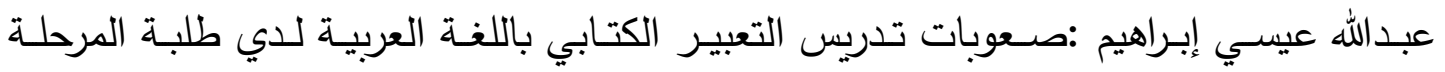

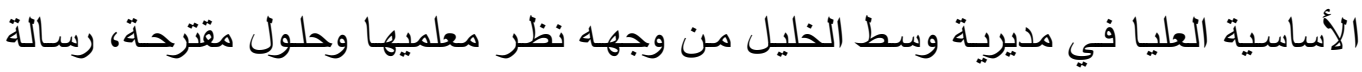

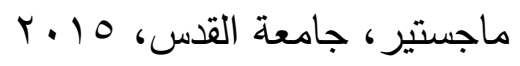
علي حسن أسـعد : صـعوبات تعلم القـراءة والكتابـة مـن وجهـهـ نظر معلمي الصـف الأول

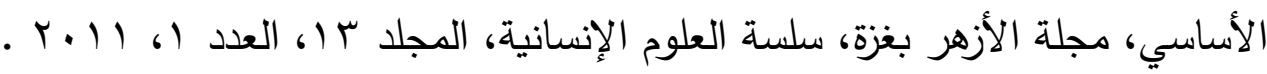


عمر المغراوي: صسوبات القراءة والكتابة وعلاقتهمـا بالتحصيل الدراسي نحو مقاربة حديثة،

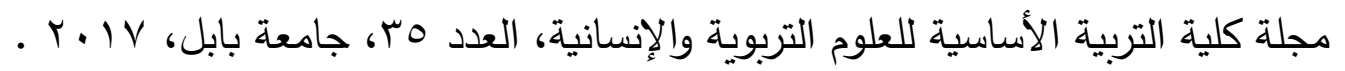
فتحي الزيـات : صـوبات تعلم القراءة وعلاقتها ببعض المتغيرات الديموغرافيـة لدي تلاميذ

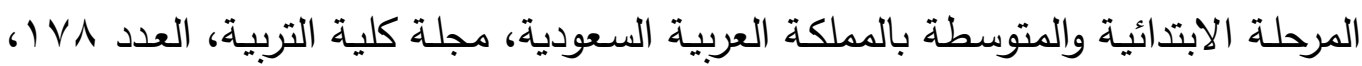

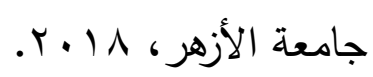

فريـال عبده أبـو سـته: اسـتراتيجيات مقترحسة لعـلاج صـعوبات القـراءة لـدي الموهـوبين ذوي صعوبات التعلم، المؤتمر الدولي الثالث للموهوبين والمتفوقين ؟ب-ج ب اكتوبر كلية التربية،

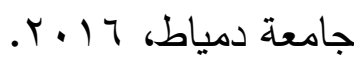
فريدة تريكي، نجوي عبادة: اكتساب مهارة الكتابة في التعليم الابتدائي دراسة ميدانية، رسالة

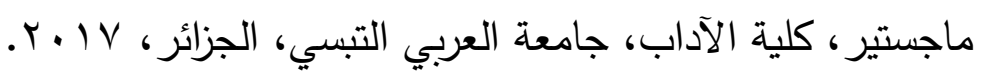

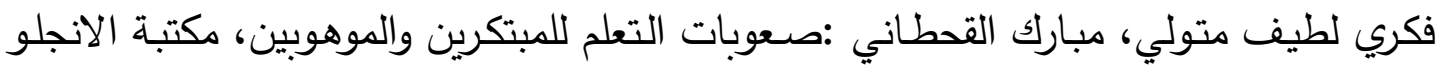

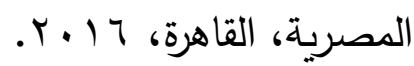
قاسم خضر : فاعلية برنامج قائم علي أنثطة الذكاءات المتعددة في تتمية بعض مهارات القراءة

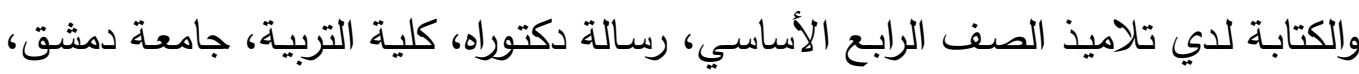
. r. Ir محمد أحمد، فراس أحمد واخرون: أثر برنامج تدريبي قائم علي مهارات الإدراك السمعي في

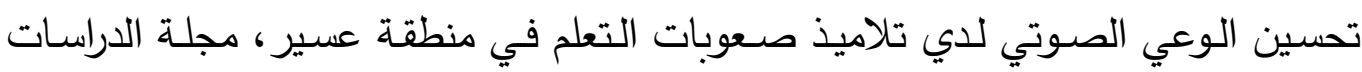

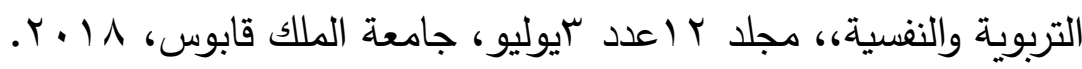
محمد السعيد وآخرون: فعالية برنامج تدريبي باستخدام الحاسوب في تتمية الوعي الفونولوجي

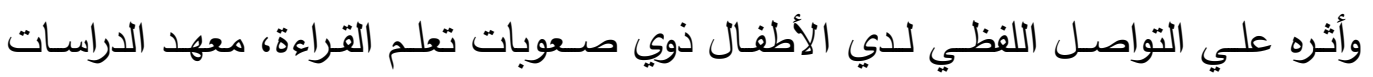

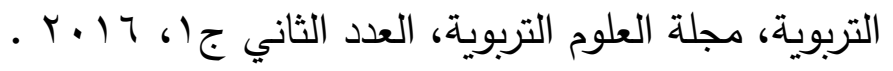

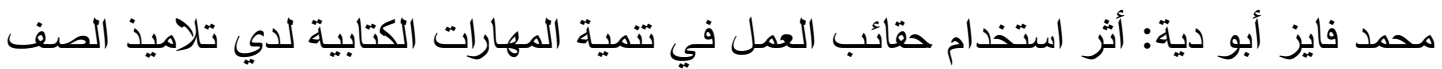
الثالث الأساسي بغزة، رسالة ماجستير، كلية التربية، الجامعة الاسلامية، غزة، 17 ــr.

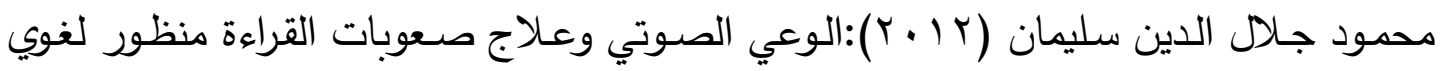
تطبيقي، القاهرة، عالم الكتب. 
محي الدين فواز : فاعلية برنامج تدريبي في تحسين القراءة الجهرية لدي التلاميذ ذوي صعوبات تعلم القراءة في ضـوء نظريـة الذكاءات المتعددة، رسـالة ماجستير ، كليـة التربيـة، جامعـة دمشق،

منصوري مصطفي وبن عروم وافية: صعوبات تعلم القراءة لدي تلاميذ السنتين الثانية والثالثة ابتدائي، مجلة دراسات نفسية وتربوية، عدد ع (، 0 1 . ب.

منصسوري مصسفي وكحلول بلقاسـ: صسوبات التعلم الأكاديميـة لدي التلاميذ الذين التحقوا بالمدرسـة قبـل سـن التمـدرس، مجلـة العلـوم النفسـية والتربويـة، العـدد بأ، جامعـة وهـران

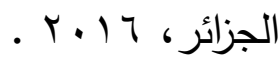

مها سلامة نصر : فاعلية استخدام استراتيجية التعليم المتمايز في تتمية مهاراتي القراءة والكتابة لدي تلاميذ الصف الثاني الابتدائي في مقرر اللغـة العربيـة، الجامعـة الاسـلامية، كليـة

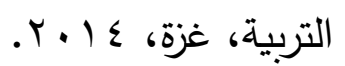

نـوال المطلق: صـعوبات تعلـم القـراءة والكتابـة وعلاقتهـا بـبعض المتغيـرات (الانتبـاه والادراك الحركي) دراسة ميدانية علي عينة من تلاميذ ذوي صعوبات التعلم من التعليم الأساسي في

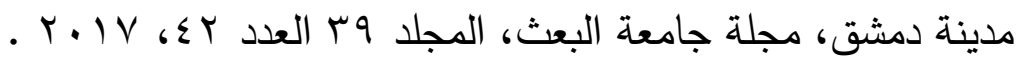
هيفة الحوامدة : بناء برنامج تعليمي قائم علي استراتيجية مطورة للقراءة وقياس أثره في تتمية القراءة الإبداعيـة والكتابـة الوظيفيـة لدي طلبـة الصـف التاسـع الأساسي، رسـالة دكتوراه،

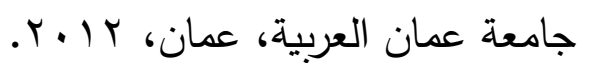
وصـال محمد جـابر : الطلبة الموهوبين ذوو صسعوبات التعلم وكيفيـة إكسابهم الاستراتيجيات

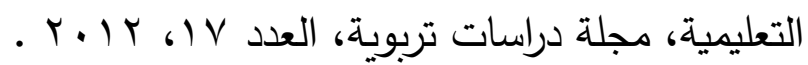

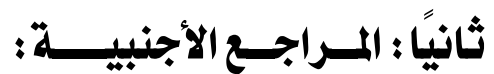

Berg, B., (2011): Impact of Phonological Awareness Instruction on Reading Fluency of Secondary Students,Publication info: Southwest Minnesota State University, ProQuest, UMI Dissertations Publishing.

Buckstein, E. (2010): The effect of explicit rhyming instruction on the phonological awareness skills and early reading abilities of kindergarten-age children, Publication info: The William Paterson University of New Jersey, ProQuest, UMI Dissertations Publishing. 
Dixon,L. (2011):Singaporean kindergartners Phonological awareness and English writing skills,journal of applied developmental psycshology,Vol.32,No. (3),june,pp.98-108.

Erdogan,O., (2011):Relationship between the Phonological awareness skills and writing skills of the first year student at primary school, journal of education sciences theory\& practice,Turkish,Vol (11)No.3,PP.1506-1510.

Falth, L.,Gustrson, S., \& Svensson, I. (2017) Phonological awareness training with articulation promotes early reading development . Education, 137 (3),261-276.

Hallahan,D. Kauffmn, and Pullen,J. (2011) Except i. Roduction to special education. (12 edition),Pearson Education Ional Learers:Int

Johnson, D., (2012): Spanish reading comprehension, phonological awareness, and oral fluency among Spanish speaking adolescent Latino students Publication info: Capella University, ProQuest, UMI Dissertations Publishing, : Ph.D.

Landgraf,S.,\&et al (2012):Impact of Phonological processing skills on written language acquisition in illiterate adults, Dev $\operatorname{cog} n$ Neuroscity journal,Germany, Vol (2),N (1),PP.29-38.

Lee, K., (2011): Relative contributions of phonological awareness and orthographic knowledge to the reading proficiency of Chinese students learning English as a foreign language Publication info: University of Houston, ProQuest, UMI Dissertations Publishing.

Lerner, J, Kline, f. (2016). Learning Disabilities and Related Disorder, Characteritics and Teaching Strategies. B0ston, New YORK, Houghton Mifflin Company.

Makhoul, B. (2016) . Moving beyond phonological awarenees ,therole of phonological awarenees skills in Arabic reading development . Journal of psycholinguist research , 46,469- 480 .

Melby, M. \& Lyster, S., \& Hulme, C., (2012): Phonological skills and their role in learning to read: ameta analytic review, Psychological Ball journal,Vol: (138),No.2,PP.32-52. 
Paige, D,Rpley , W , smith, G, olinger C, \& Leslie M (2018). Acquisition of letter naming knowledge , phonological awareness, and spelling knowledge of kindergarten children at risk for learning to read . child development research, 1-10 doi 10.1155 / 2018 / 214294.2018 : 1-10 .

Pannell, M., (2012): Relationships Between Reading Ability in Third Grade and Phonological Awareness in Kindergarten Publication info: East Tennessee State University, ProQuest, UMI Dissertations Publishing,

Pavelko, S ., Liebrman, J, Schartz, J., Hahs- Vaughn, D . (2018) . The contributions of Phonological awareness, alphabet.

Penke, M., (2009):The role of phonology in reading, written language and literacy journal,Vol (11)No. (2),PP. (147-166).

Robinson, S., (2010):The effects of embedded phonological awareness training on the reading and spelling skills of kindergarten students, Publication info: The University of North Dakota, ProQuest, UMI Dissertations Publishing: Ph.D.

Schrmm,L. (2016) The Effects Of Using Direct Instruction And Computer - Assisted Instruction On Teaching Decoding Skill To Elementary Students With Learning Disabilities .Published $\mathrm{M}$ aster,s Thesis Rowan University,U.S.A.

Stothers,M.,\&Klein,P., (2010):Perceptual Organization ,Phonological awareness, and reading comprehension in adults with and without learning disabilities, international dyslexia association published online,septemper, available at:www.mercercog native psychology.pb works.com.

Workbase,supporting worforce for literacy (2010):Decoding:phonics for adult www.pyzam.com.

Yeung,S., (2013): Effects of Phonological awareness program on English reading and spilling among Hong Kong Chinese, ESL children, Facualty of educate university of Hong Kong, available at :www.academia,edu.

Zgonc, Y., (2010): Intervention for all phonological awareness, Crystal springs Books,USA.PP.22-25. 